\title{
Forest Fires in Madeira Island and the Fire Weather Created by Orographic Effects
}

\author{
Flavio T. Couto ${ }^{1,2, *}$, Rui Salgado ${ }^{1,2,3} \mathbb{D}$ and Nuno Guiomar ${ }^{4}(\mathbb{D}$ \\ 1 Instituto de Ciências da Terra-ICT (Polo de Évora), Universidade de Évora, Rua Romão Ramalho, 59, \\ 7000-671 Évora, Portugal; rsal@uevora.pt \\ 2 Earth Remote Sensing Laboratory (EaRS Lab), Universidade de Évora, Rua Romão Ramalho, 59, \\ 7000-671 Évora, Portugal \\ 3 Departamento de Física, Escola de Ciências e Tecnologia, Universidade de Évora, Rua Romão Ramalho, 59, \\ 7000-671 Évora, Portugal \\ 4 MED-Mediterranean Institute for Agriculture, Environment and Development, Instituto de Investigação e \\ Formação Avançada, Universidade de Évora, 7006-554 Évora, Portugal; nunogui@uevora.pt \\ * Correspondence: fcouto@uevora.pt
}

Citation: Couto, F.T.; Salgado, R.; Guiomar, N. Forest Fires in Madeira Island and the Fire Weather Created by Orographic Effects. Atmosphere 2021, 12, 827. https://doi.org/ $10.3390 /$ atmos 12070827

Academic Editor: Jason C. Knievel

Received: 19 May 2021

Accepted: 25 June 2021

Published: 28 June 2021

Publisher's Note: MDPI stays neutral with regard to jurisdictional claims in published maps and institutional affiliations.

Copyright: (c) 2021 by the authors. Licensee MDPI, Basel, Switzerland. This article is an open access article distributed under the terms and conditions of the Creative Commons Attribution (CC BY) license (https:// creativecommons.org/licenses/by/ $4.0 /)$.

\begin{abstract}
Understanding the effects of weather and topography on fire spread in specific contexts, such as oceanic islands, is critical for supporting fire prevention and suppression strategies. In this study, we analyse the atmospheric conditions associated with historical forest fires that have occurred over complex terrain in Madeira Island, Portugal. The atmospheric Meso-NH model was used to identify the mesoscale environment during three forest fires events. The model was configured into two nested horizontal domains, the outer domain at $2.5 \mathrm{~km}$ resolution and the inner domain at $500 \mathrm{~m}$. The paper brings a comprehensive analysis on the factors favouring the evolution of significant large fires occurring in Madeira Island in August 2010, July 2012 and August 2016. These fire events were selected because they are characterized by their large size (between 324.99 ha and 7691.67 ha) that expanded in a short-time period, threatening people and property in the wildland-urban interfaces. The study highlights that local terrain produce orographic effects that enhance the fire danger over the southern slope during typical summer atmospheric conditions.
\end{abstract}

Keywords: fire weather; orographic effects; Madeira Island; Meso-NH model

\section{Introduction}

The atmospheric circulation over complex terrain induces several meteorological phenomena. The orographic effects may be triggered as air flows toward a mountain barrier, depending on mountain shape and on its own flow regime. In general, it may be forced to flow upslope on the windward side and descend on the lee side, or still be blockaded or deviated by such an obstacle, depending on the dynamical and thermal stability. In many mountainous regions, clouds and heavy precipitation development can be observed as result of complex interactions between air circulation and topography [1,2]. Airflow crossing a mountain ridge may also produce other atmospheric phenomena with significant impacts at surface level. Diurnal mountain winds, dynamic channelling, foehn winds, low level jets or mountain waves are examples of orographic effects on airflow properties that can change their main characteristics (e.g., temperature, relative humidity, wind speed and direction, atmospheric stability) and, in a context of fire propagation, also change fire behaviour [3].

In California, extreme fire events quickly spread following strong hot and dry winds, such as the Tubbs fire in October 2017 [4]. The fluctuations in climate conditions are another factor that may contribute to unexpected wildfires [5]. The High Park wildfire in 2012 was ignited under drought conditions just before an unseasonal downslope wind-storm [6], characterized by extreme gusty surface winds that substantially increased fire spread rate. 
Currently, one of the most relevant scientific challenges is to understand shifts in fire regimes, particularly related with the potential distribution of extreme fire events under the expected climate changes. In Australia, extreme wildfires are expected to be more frequent due to an increase in frequency of more hazardous fire weather conditions in many of the southern regions [7], as well as the expansion of the extreme wildfires season in the spring [8]. The same scenario is documented in several regions of the United States of America [9,10], already showing significant increasing trends of high severely burned areas across the south-west in all types of forest and woodland ecosystems [11].

It is well known that climate factors influence fire activity by determining fuel characteristics in the long-term, whereas the weather conditions affect fire behaviour in the short-term. However, the risk assessment of a potential intensification of wildfires from the expected changes in weather conditions is still a challenge worldwide, in particular due to the phenomena triggered by the interaction between fire and atmosphere that can create firestorms and unexpected fire behaviour [12,13].

In recent decades, fire modeling and simulation has evolved considerably, increasing its applicability in decision support both in fire prevention and fuel management contexts [14] and in the definition of fire suppression strategies and tactics [15]. Physicallybased, empirical and semi-empirical models were developed and applied [16-19], as well as approaches and tools that couple fire surface models with fire-atmosphere models [20-22]. More recently, studies have been conducted to test and validate coupled fire-atmosphere models using real fire data [23] and to increase its operational capacity when integrated in fire spread forecasting systems [24]; to reduce uncertainty in fire spread predictions through real-time adjustments in fire simulation [25]; or to increase understanding on the interactive effects between different drivers on fire spread in high impact fires [26]. Efforts have also been dedicated to the use of convection-permitting simulation with an explicit electrical scheme to assess the current possibility of representing lightning phenomena during the early stages of forest fire development [27]. Lightning is the main natural fire ignition source around the globe [28], which often accumulates conditions for extreme fire propagation, especially after the disintegration of the cells creating local downdrafts characterized by strong and erratic winds. Besides the dry surface conditions, lightning strikes from thunderstorms in the dissipating stage were the dominant fire ignition source during the 2014 fire season in the Northwest regions of Canada [29].

Extreme fire events result in loss of life and property causing damages to the society [30]. The extensive study of different factors exacerbating extreme fire behaviour is critical to better understand how fire may be influenced by the atmospheric conditions, which may rapidly change and affect fire spread and intensity to thresholds above suppression capacity.

In 2017, an extreme fire season affected Portugal and Spain. In Portugal, the first deadly event occurred in the region of Pedrógão Grande, causing more than 60 fatalities in June $[27,31]$. In late June, the forest fires in Southern Spain affected the Doñana Natural Park with a direct impact in biodiversity. The extreme meteorological conditions of temperature, relative humidity, and wind speed induced the rapid fire spread toward the Natural Park affecting many endangered plant and animal species [32]. Months later, on mid-October, extreme wildfires spread again across the Central region of Portugal mainland resulting in 48 fatalities [33]. Such extreme fire events contributed to the creation of the "Iberian Centre for Research and Forest Firefighting" (CILIFO, www.cilifo.eu, last accessed 17 May 2021), which has an operational framework covering the Portuguese regions of Alentejo and Algarve, as well as the Andalusia in Southern Spain.

Both surface conditions, as terrain and fuel moisture, and atmospheric conditions, as high temperature and low relative humidity, are recognized as factors favouring forest fire occurrence and propagation [34]. Therefore, under the CILIFO framework, namely in the context of characterization of meteorological environments that favour the evolution of significant large and extreme fires, this study aims to identify the atmospheric conditions associated with forest fires that have occurred in complex terrain landscapes 
of Madeira Island using convection-permitting simulations. The paper is organized as follows: Section 2 presents the study region and case studies, as well as the data used and numerical modelling aspects. In Section 3 the results are presented, which are summarized in Section 4 jointly with the conclusions.

\section{Study Region, Case Studies and Numerical Modelling}

\subsection{Study Region}

Madeira is a Portuguese island located in the North Atlantic Ocean at $32^{\circ} 75 \mathrm{~N}$ and $17^{\circ} 00 \mathrm{~W}$ (Figure 1). It is the largest island of the archipelago with approximately $740 \mathrm{~km}^{2}$, with an east-west elongated form, and a central mountain chain characterised by deep valleys, cliffs, and peaks up to above $1800 \mathrm{~m}$ in the eastern region. Such geography contributes to Madeira's climate, defined by dry summers and wet winters [35]. The precipitation is strongly correlated with the local orography, as observed in studies during the winter [36] and autumn seasons [37,38]. When extreme, the precipitating events may have a significant impact at surface, resulting in flash floods and landslides [39-41]. In addition, the mountains favour the development of orographic fogs throughout the year [42-44], as well as dense vegetation [45]. Forest fires may be observed in the island during the summertime. Forest stands cover $45 \%$ of Madeira (34,044 ha), while shrubland and natural grasslands cover $25 \%$ (24,255 ha), and extreme fire events pose a threat to these ecosystems and to local economy [46].

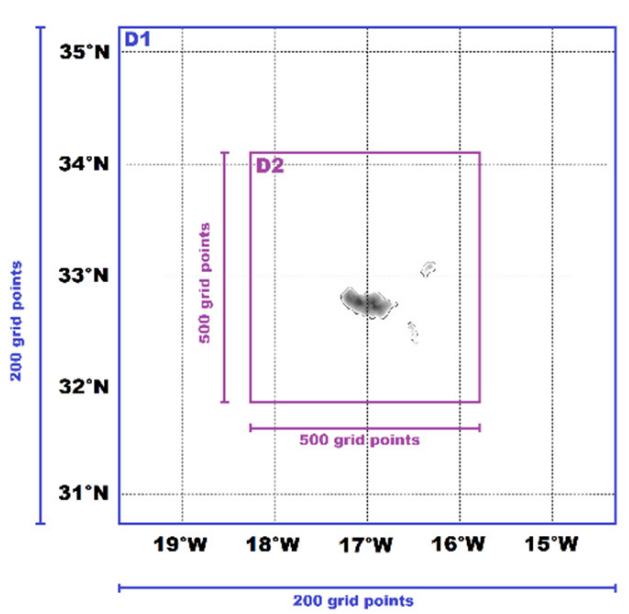

(a)

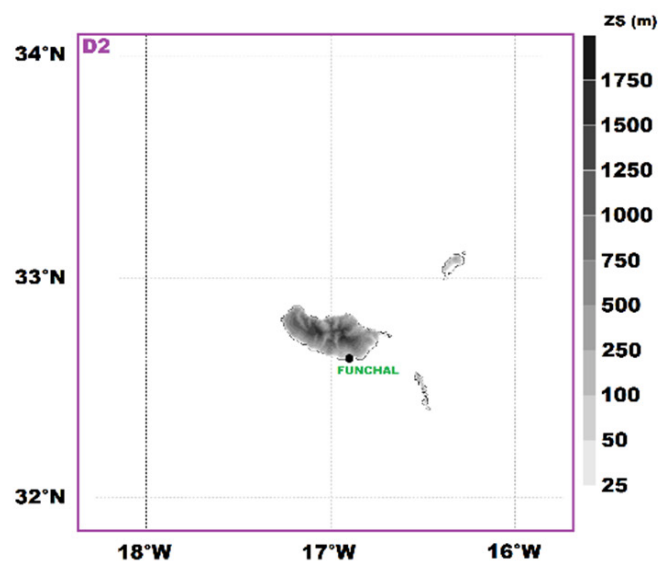

(b)

Figure 1. Meso-NH configuration and Madeira island location with orography obtained from the SRTM database. (a) Outer domain at $2.5 \mathrm{~km}$ resolution; (b) Inner domain at $500 \mathrm{~m}$ resolution.

\subsection{Case Studies (Historical Events)}

In the last 15 years, the island was affected by several wildfires, some of them resulting in large burned areas. Figure 2 shows the annual distribution of the number of fires and burned area affecting forest stands and shrubland between 2000 and 2016. The years 2010, 2012 and 2016 stand out clearly from the remaining years, with more than 6000 ha of burnt forests and shrubland ([47], and Paulo Fernandes—see acknowledgments). These three years were then selected to be analysed in terms of fire weather conditions. The events occurred in the following periods: 12 and 13 August 2010; 18 and 19 July 2012; and 08-10 August 2016. 


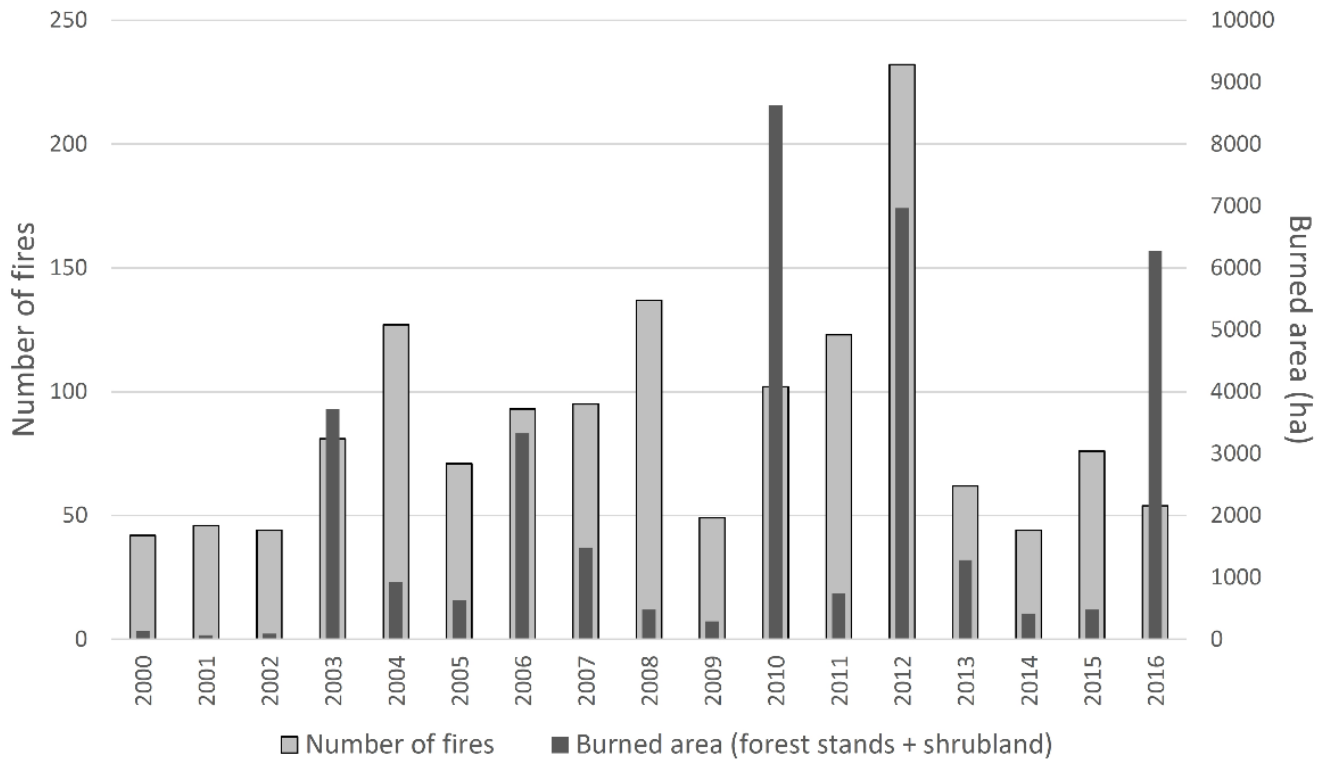

Figure 2. Annual distribution of the number of fires and burned area affecting forest patches and shrubland between 2000 and 2016. The official statistical data presented here did not count the total burned area, only the area affected by fire covered by forest stands and shrubland. Data source: based on official statistics published in [47] for the period between 2006 and 2016; and Paulo Fernandes for the period between 2000 and 2005 (see acknowledgments).

The satellite images presented in Figure 3 were obtained from the MODIS Aqua satellite observations available in the NASA's observatory website (accessed in December 2020). In each satellite image displayed in Figure 3, the active fires can be easily identified through the smoke being transported southward. The red line contour in Figure 3a shows that in Period 1 the forest fires occurred mainly in the Madeira highlands, namely over the central part of the island in the eastern peak. Figure $3 \mathrm{~b}$ shows forest fires occurring in the extreme west and southern slope regions during Period 2, and in larger extension in the extreme east of the island. In Period 3, Figure 3c shows the fires on August 2016 in the southern slope. For this third period, Figure $3 \mathrm{~d}$ shows the dimension of the burned areas which also affected the foothills of the island, namely the wildland-urban interface near the Funchal city in the south-eastern region, causing three fatalities, more than 300 houses destroyed, a thousand displaced people, and $\sim 61$ million EUR of damages [46].

In fact, these years can be characterized by a small number of large and atypical fires that contributed to most of the burned area (Table 1), as can be seen in Figure 4. These fires spread very quickly over a short period of time, some of which resulted from more than one ignition (e.g., fire $\mathrm{H}$ in Figure 4). 


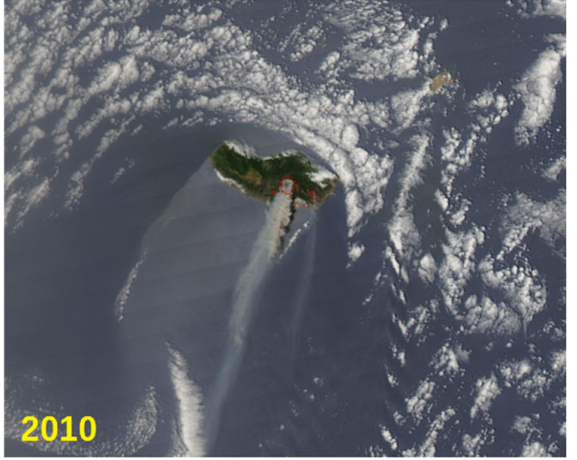

(a)

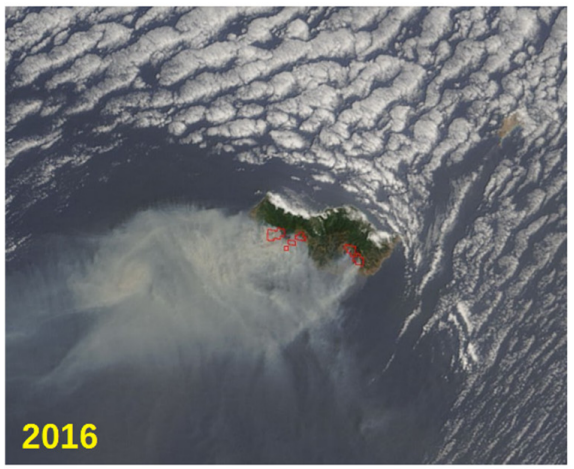

(c)

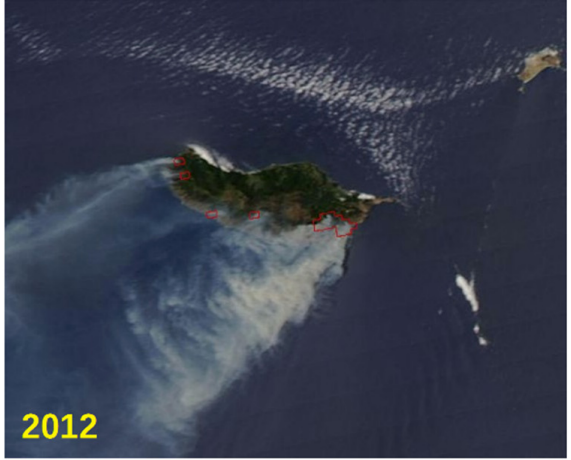

(b)

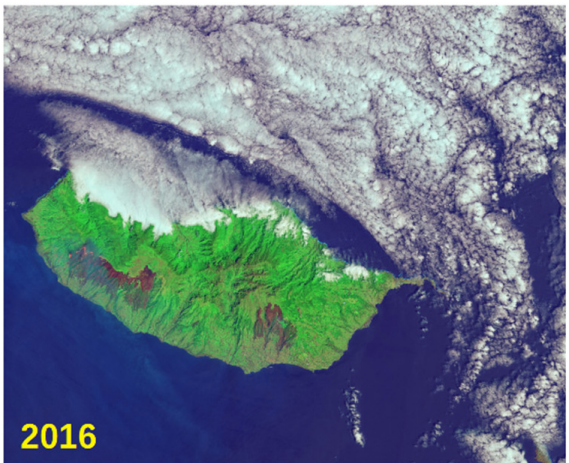

(d)

Figure 3. Satellite observations for each period considered in the study available in the NASA's observatory website: (a) 13 August 2010 [48]; (b) 19 July 2012 [49], and (c) 08 August 2016 [50]. (d) The burned area on 11 August 2016 [51].

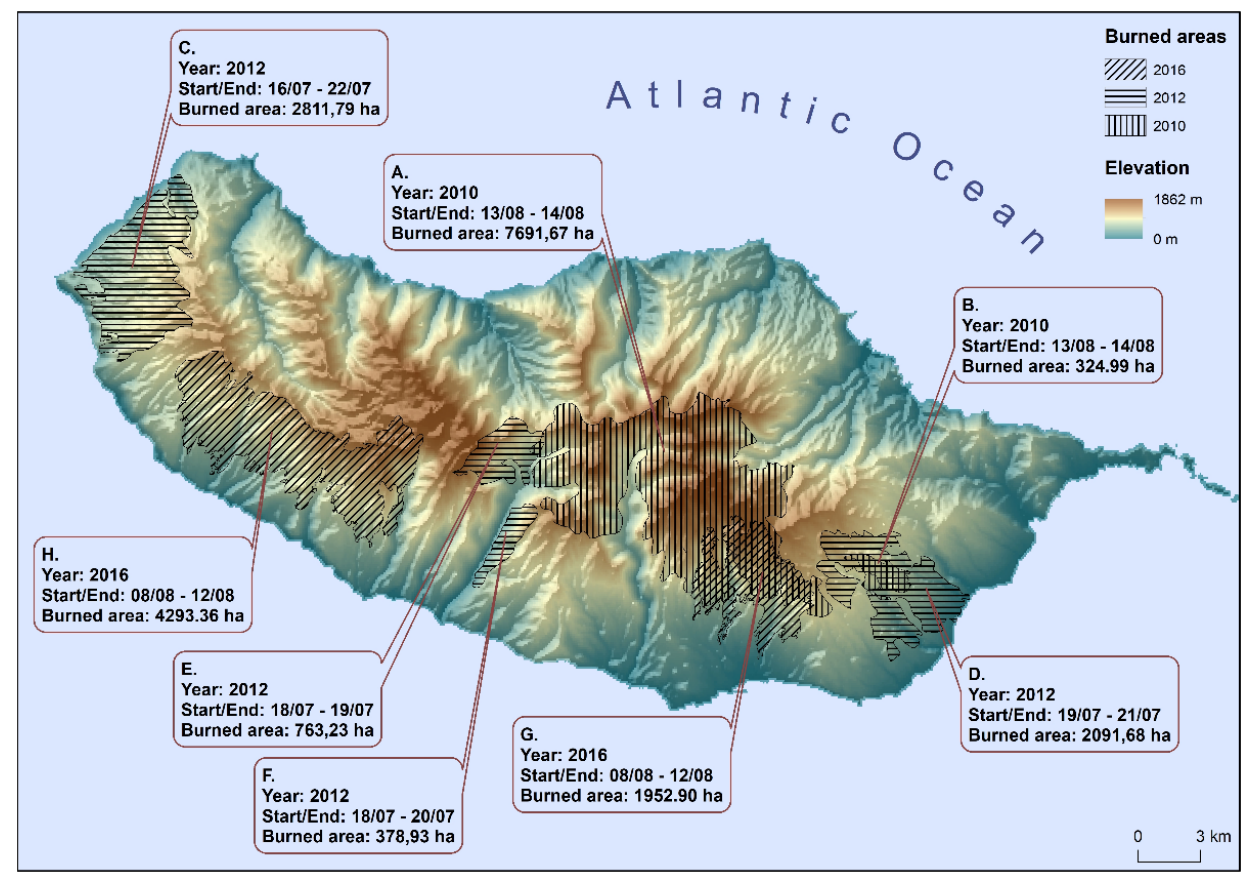

Figure 4. Spatial distribution of the large fires occurred in 2010, 2012 and 2016. Source: Authors, based on data provided by Paulo Fernandes (see acknowledgements); Hillshade was calculated using the SRTM 90 m DEM version 4. 
Table 1. Main characteristics of fire propagation on the target-days analysed. TBA: Total burned area by the large fires analysed; \%ABA (F+S): Percentage of annual burned area covered by forest stands and shrubland (in relation to the official statistics provided in Figure 2); FRP: Fire Radiative Power. Note: The daily expansion rates were estimated based on the fire hotspots data of MODIS and VIIRS sensors, and adjusted for each day.

\begin{tabular}{|c|c|c|c|c|c|c|c|c|c|c|}
\hline \multirow[t]{2}{*}{ Year } & \multirow[t]{2}{*}{ TBA } & \multirow{2}{*}{$\begin{array}{c}\% \text { ABA } \\
(\mathrm{F}+\mathrm{S})\end{array}$} & \multicolumn{4}{|c|}{ Daily Expansion Rate (ha/h) } & \multirow[b]{2}{*}{$\mathbf{N}$} & \multicolumn{3}{|c|}{$\begin{array}{c}\text { FRP } \\
\text { MODIS (VIIRS) }\end{array}$} \\
\hline & & & Day & Mean & & Max. & & Mean & P95 & Max. \\
\hline \multirow{2}{*}{2010} & \multirow{2}{*}{8016.66} & \multirow{2}{*}{$89.84 \%$} & $13 / 08$ & 244.80 & 745.01 & 1234-1411UTC & 75 & 144.2 & 680.1 & 1488.1 \\
\hline & & & $14 / 08$ & 165.80 & 324.48 & 0215-0353UTC & 17 & 155.4 & 297.6 & 297.6 \\
\hline \multirow{7}{*}{2012} & \multirow{7}{*}{6045.64} & \multirow{7}{*}{$69.04 \%$} & $16 / 07$ & 2.46 & 7.61 & 0000-0359UTC & $\begin{array}{c}- \\
(4)\end{array}$ & $\begin{array}{c}- \\
(2.7)\end{array}$ & $\begin{array}{c}- \\
(4.5)\end{array}$ & $\begin{array}{c}- \\
(4.5)\end{array}$ \\
\hline & & & $17 / 07$ & 24.86 & 16.99 & 0340-1318UTC & $\begin{array}{l}10 \\
(9)\end{array}$ & $\begin{array}{l}84.9 \\
(9.2)\end{array}$ & $\begin{array}{c}372.0 \\
(15.3)\end{array}$ & $\begin{array}{l}372.0 \\
(15.3)\end{array}$ \\
\hline & & & $18 / 07$ & 82.09 & 102.70 & 0321-1440UTC & $\begin{array}{c}38 \\
(74)\end{array}$ & $\begin{array}{l}102.4 \\
(18.4)\end{array}$ & $\begin{array}{l}364.8 \\
(47.0)\end{array}$ & $\begin{array}{c}432.3 \\
(142.8)\end{array}$ \\
\hline & & & $19 / 07$ & 172.95 & 290.37 & 0303-1421UTC & $\begin{array}{c}69 \\
(136)\end{array}$ & $\begin{array}{l}113.1 \\
(31.1)\end{array}$ & $\begin{array}{l}586.6 \\
(91.2)\end{array}$ & $\begin{array}{c}847.3 \\
(157.0)\end{array}$ \\
\hline & & & $20 / 07$ & 35.00 & 93.71 & 0000-0244UTC & $\begin{array}{c}3 \\
(90)\end{array}$ & $\begin{array}{l}58.2 \\
(7.2)\end{array}$ & $\begin{array}{c}81.2 \\
(41.4)\end{array}$ & $\begin{array}{c}81.2 \\
(51.3)\end{array}$ \\
\hline & & & $21 / 07$ & 17.20 & 18.80 & 0225-1343UTC & $\begin{array}{c}7 \\
(16)\end{array}$ & $\begin{array}{l}60.7 \\
(4.0)\end{array}$ & $\begin{array}{l}264.5 \\
(10.6)\end{array}$ & $\begin{array}{l}264.5 \\
(10.6)\end{array}$ \\
\hline & & & $22 / 07$ & 8.79 & 22.58 & 0206-0346UTC & $\begin{array}{c}2 \\
(11)\end{array}$ & $\begin{array}{l}22.8 \\
(5.9)\end{array}$ & $\begin{array}{c}29.0 \\
(13.4)\end{array}$ & $\begin{array}{c}29.0 \\
(13.4)\end{array}$ \\
\hline \multirow{5}{*}{2016} & \multirow{5}{*}{6246.25} & \multirow{5}{*}{$91.79 \%$} & $8 / 08$ & 60.80 & 88.61 & 1455-2400UTC & $\begin{array}{l}22 \\
(5)\end{array}$ & $\begin{array}{l}101.6 \\
(30.9)\end{array}$ & $\begin{array}{c}265,1 \\
(127.9)\end{array}$ & $\begin{array}{c}554.4 \\
(127.9)\end{array}$ \\
\hline & & & $9 / 08$ & 76.65 & 139.38 & 1436-2400UTC & $\begin{array}{c}25 \\
(101)\end{array}$ & $\begin{array}{l}111.5 \\
(20.5)\end{array}$ & $\begin{array}{l}321.5 \\
(146.0)\end{array}$ & $\begin{array}{l}398.6 \\
(95.7)\end{array}$ \\
\hline & & & $10 / 08$ & 131.72 & 203.26 & 0259-1417UTC & $\begin{array}{c}54 \\
(185)\end{array}$ & $\begin{array}{c}80.9 \\
(14.9)\end{array}$ & $\begin{array}{l}204.5 \\
(55.7)\end{array}$ & $\begin{array}{c}293.6 \\
(136.4)\end{array}$ \\
\hline & & & $11 / 08$ & 29.92 & 40.86 & 0000-0240UTC & $\begin{array}{c}17 \\
(59)\end{array}$ & $\begin{array}{c}98.3 \\
(15.1)\end{array}$ & $\begin{array}{l}519.5 \\
(49.0)\end{array}$ & $\begin{array}{l}519.5 \\
(69.8)\end{array}$ \\
\hline & & & $12 / 08$ & 12.28 & 12.28 & 0000-0401UTC & $\begin{array}{c}2 \\
(15)\end{array}$ & $\begin{array}{l}34.9 \\
(7.7)\end{array}$ & $\begin{array}{c}53.2 \\
(20.3)\end{array}$ & $\begin{array}{c}53.2 \\
(20.3)\end{array}$ \\
\hline
\end{tabular}

The hotspots data from the MODIS and VIIRS sensors allowed dividing the target fires into periods (Table 1) and estimating the expansion rates in each of them. Additionally, we added some descriptive data for the Fire Radiative Power for each day, separating the measurements from the two sensors, since there are considerable differences between them. This previous assessment allowed the selection of the following periods to conduct the further analysis: (1) 12 and 13 August 2010 (Figure 3a); (2) 18 and 19 July 2012 (Figure 3b); (3) 08 to 10 August 2016 (Figure 3c). The satellite images presented in Figure 3 were obtained from the MODIS Aqua satellite observations available in the NASA's observatory website (accessed in December 2020).

\subsection{Numerical Simulations and Model Validation}

The numerical simulations were performed using the Meso- $\mathrm{NH}$, a non-hydrostatic model able to represent the atmospheric environments in different time and spatial scales, with a wide range of parametrization schemes for several physical processes observed in the Earth's atmosphere [52,53]. Here, it was configured into two domains as shown in Figure 1. The outer domain was configured with $200 \times 200$ grid points and $2.5 \mathrm{~km}$ resolution. To access the effects of the rugged local surface, an inner domain was designed with a resolution of $500 \mathrm{~m}(500 \times 500$ grid points $)$, capable of better representing the complex terrain characteristic of the mountainous island. The vertical grid was calculated automatically by the model with a total of 50 levels following the terrain. The simulations were performed in a two-way interactive mode, initialized and forced using the European Centre for Medium-Range Weather Forecasts (ECMWF) analysis updated each $6 \mathrm{~h}$. 
In the present study, the convection-permitting simulations were performed with a parametrization configuration similar to those successfully used in previous studies over the island [37]. Namely, the radiation parametrization is based on the Rapid Radiative Transfer Model [54], whereas for the turbulence the 1D scheme [55] was used in the larger domain and the 3D scheme [56] in the smaller domain. The deep convection was assumed to be explicitly resolved and the shallow convection was parametrized only for the $2.5 \mathrm{~km}$ coarser domain [57]. The parametrization of cloud microphysics was made using the one-moment ICE3 scheme [58], which is able to represent five hydrometeor species for the water substance. Finally, the surface variables were obtained from the externalized SURFEX model coupled to the Meso-NH [59].

This configuration was applied for the three periods mentioned in Section 2.2. Each simulation starts on the day when the fires were ignited. For the first $12 \mathrm{~h}$ of each simulation, the model was run only over the larger domain, whereas in nested mode until the end of the experiment, i.e., $36 \mathrm{~h}$ for August 2010 and July 2012, and $60 \mathrm{~h}$ for August 2016. Such a configuration was chosen in order to assess the prevailing weather conditions encompassing the fire events. The interactions between the fires and the atmosphere were not taken into account in the experiments.

The model validation is made from a point to point comparison between observed and simulated time series. The meteorological variables verified were wind gusts, wind direction, air temperature at $2 \mathrm{~m}$, and relative humidity at $2 \mathrm{~m}$. Figure 5 shows some plots for three different meteorological stations: Areeiro (latitude: 32.72, longitude: -16.91), Ponta do Pargo (latitude: 32.81, longitude: -17.26) and Funchal (latitude: 32.64, longitude: -16.89). Such a comparison was applied for the three events considered in the study.

For the most significant event, which occurred in August 2016, Figure 5a shows that the model well captures the wind gusts in the Madeira highlands (Areeiro station), as well as the air temperature behaviour during the period (Figure 5b). In the Ponta do Pargo station (Figure 5c), the wind gusts are overestimated by the model in the first $24 \mathrm{~h}$ of simulation, but the temporal behaviour is well represented. In Funchal station, a similar result is found with a good representation of the wind pattern, but with the wind gusts being somewhat overestimated by the model during the entire period (Figure $5 \mathrm{~d}$ ). On the other hand, and despite some discrepancy in the last hours of the simulation, very good results are obtained for the air temperature and relative humidity at $2 \mathrm{~m}$, (see Figure $5 \mathrm{e}, \mathrm{f}$, respectively for Funchal). The high air temperature in Funchal, above $35^{\circ} \mathrm{C}$, is slightly overestimated by the model (Figure $5 \mathrm{e}$ ), whereas the very low relative humidity values around $15 \%$ are well simulated by the model (Figure $5 \mathrm{f}$ ).

The comparisons for the other two episodes also show the ability of the model in reproducing the weather evolution, although the point-by-point comparison revealed greater differences, partially due to local effects, more visible in lighter wind situations. We select two examples. For the episode in 2012, Figure 5g indicates that the model well captures the air temperature in the Madeira highlands (Areeiro station). In the same Areeiro station (Figure 5h), the model also captures the air temperature behaviour along the 2010 period, but with a significant underestimation of the observed values. The higher observed temperatures may be a consequence of the wildfire that occurred precisely in this region, whose effects were not taken into account by the model. 


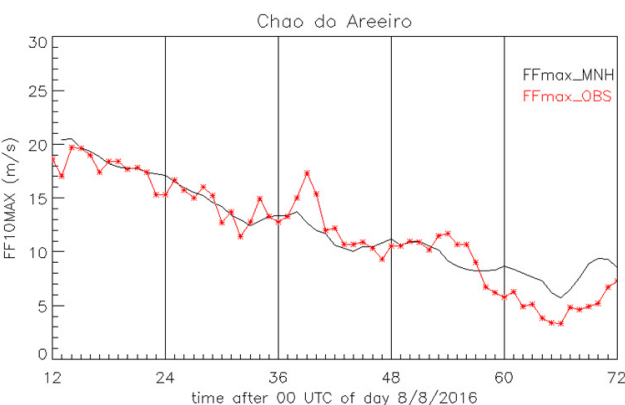

(a)

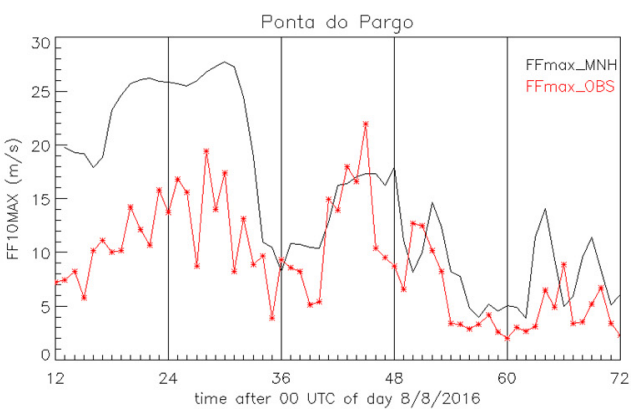

(c)

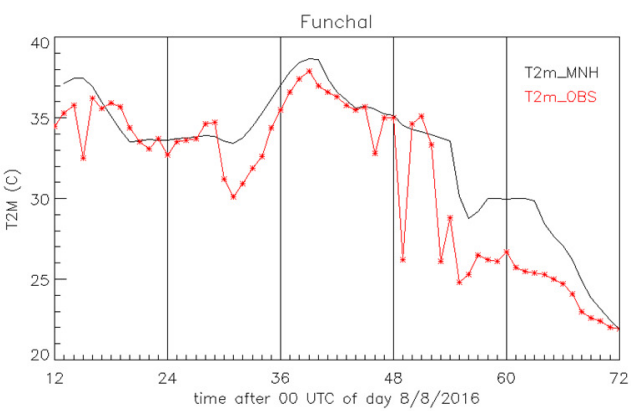

(e)

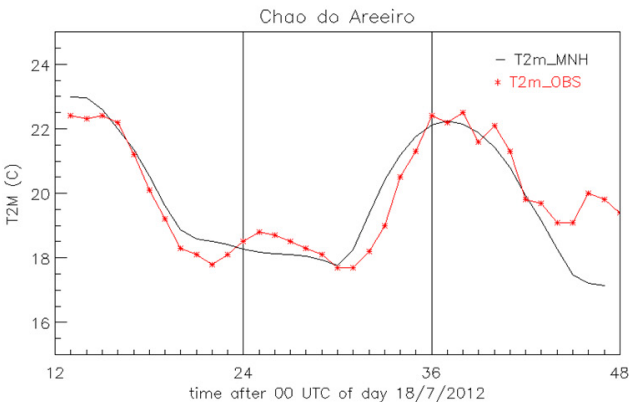

(g)

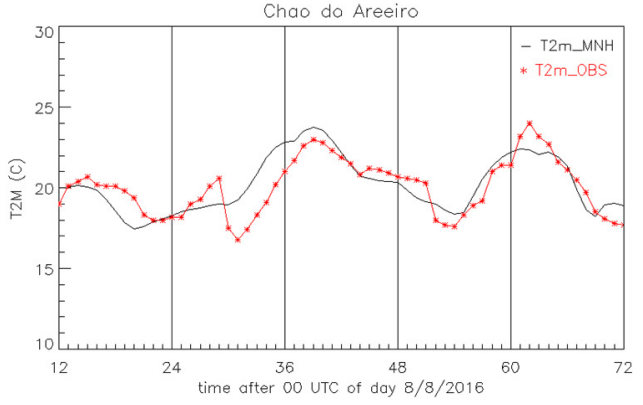

(b)

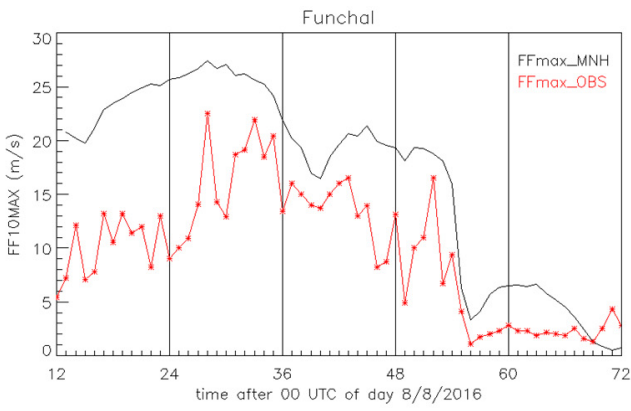

(d)

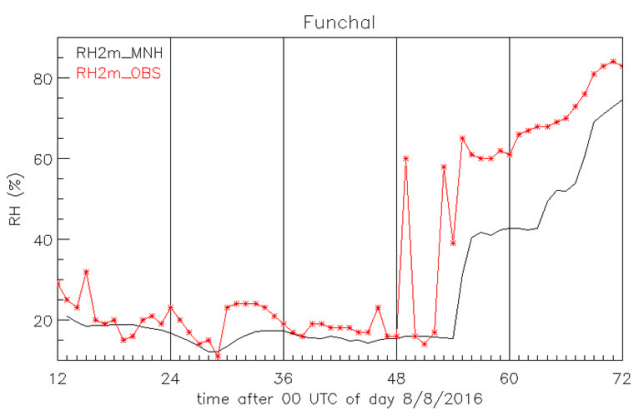

(f)

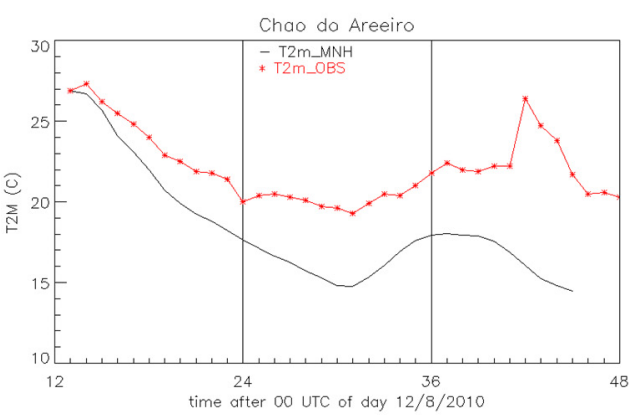

(h)

Figure 5. (a)-(h) represent time series point to point comparison between observations and simulations at $500 \mathrm{~m}$ horizontal resolution.

\section{Results}

\subsection{Synoptic Environment}

The sea level pressure and wind vectors at $1000 \mathrm{mb}$ are shown in Figure 6 representing the large scale circulation during the first day of each episode. The fields of sea level pressure and wind vectors at $1000 \mathrm{mb}$ have a uniform latitude-longitude $2.5^{\circ}$ resolution grid [60] and were used to identify the synoptic situation near the surface. The data was obtained from the 6-hourly NCEP/NCAR Reanalysis Data Composites [61]. On 12 August 
2010, corresponding to the first period, Figure 6a shows the Azores's Anticyclone centred at $52^{\circ} \mathrm{N}$ and $20^{\circ} \mathrm{W}$. Near the surface, the associated circulation favours north-easterly winds over the island. The episode that occurred in July 2012 is also linked to the presence of an anticyclone system over the North Atlantic Ocean (Figure 6b). It is centred at around $35^{\circ} \mathrm{N}$ and $30^{\circ} \mathrm{W}$, but still induces north-easterly winds, although northerly winds could rule over the island of Madeira. For the third period, namely in August 2016, a large-scale configuration similar to the first episode can be observed in Figure 6c, i.e., the Azores anticyclone centred in higher latitudes $\left(53^{\circ} \mathrm{N}\right.$ and $\left.25^{\circ} \mathrm{W}\right)$ which lead to north-easterly winds affecting the island.

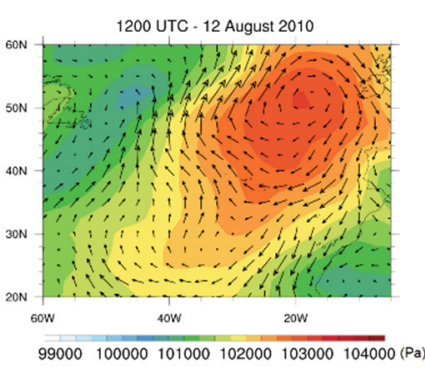

(a)

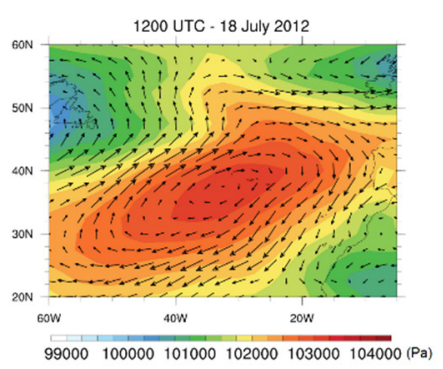

(b)

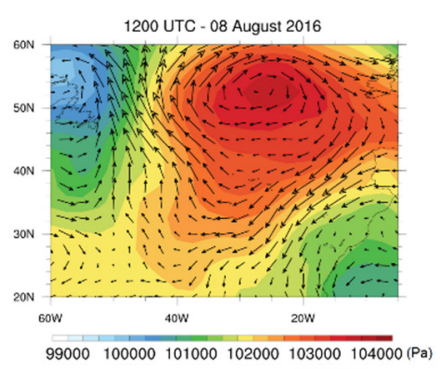

(c)

Figure 6. Sea level pressure and wind vectors at $1000 \mathrm{mb}$ at 1200 UTC on (a) 12 August 2010; (b) 18 July 2012 and (c) 08 August 2016. Source: [61].

\subsection{Mesoscale Environment and Fire Weather Conditions}

For each period, simulations at $500 \mathrm{~m}$ horizontal resolution were conducted to identify the meteorological conditions that influenced the development of the above mentioned large fires. Each section begins with the results for the airflow affecting the island, followed by the analysis of the air temperature and relative humidity fields at $2 \mathrm{~m}$.

\subsubsection{Period 1: 12 and 13 August 2010}

The north-easterly flow affecting the island identified in Figure 6 was analysed for each period aiming to determine the wind intensity from the high-resolution simulations. The vertical profiles in Figure 7 were obtained at the points A, B and C indicated in the bottom of the Figure 7. On the first day, the winds affecting the Point A present an intensity weaker than $11 \mathrm{~m} / \mathrm{s}$ in the lower troposphere (Figure 7a) and are less intense as they approach the island (Point B; Figure 7b). At Point A, the vertical profiles in Figure 7d,g show an intensification of the airflow during the night and following day, respectively. The airflow around $1500 \mathrm{~m}$ present velocities around $15 \mathrm{~m} / \mathrm{s}$ (Figure $7 \mathrm{~d}$ ) and $16.5 \mathrm{~m} / \mathrm{s}$ (Figure 7g). The mountain effect over Point B (Figure 7e,h) is also evident, with weak winds near the surface rapidly increasing in magnitude up to the top of the island around $1500 \mathrm{~m}$.

On the lee side of the island, Point $C$, there is a stagnation of large-scale circulation close to the surface, with a minimum in wind speed at about $800 \mathrm{~m}$ (Figure $7 \mathrm{c}, \mathrm{f}, \mathrm{i})$. This stagnation creates conditions for the development of a local thermal circulation, a sea breeze that is maintained even during nighttime, which increases the wind speed towards the island in the first several hundreds of meters close to the surface. 


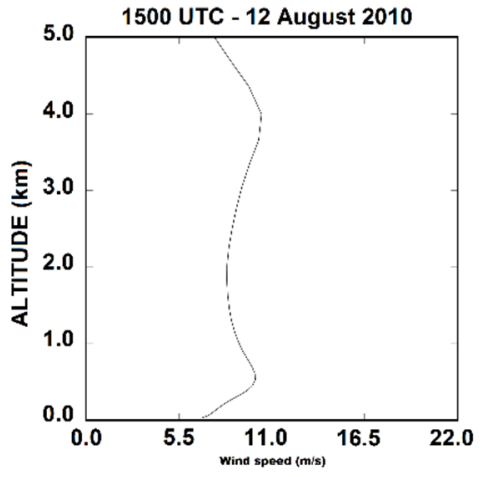

(a)

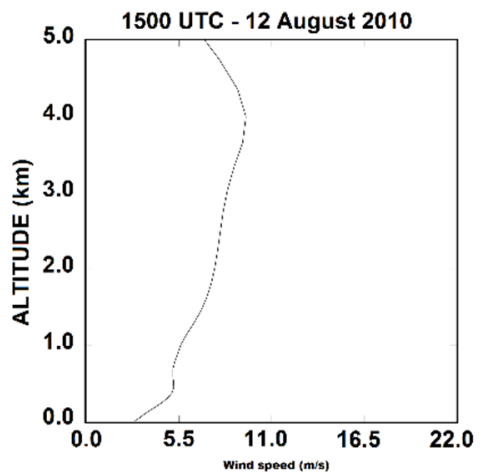

(b)

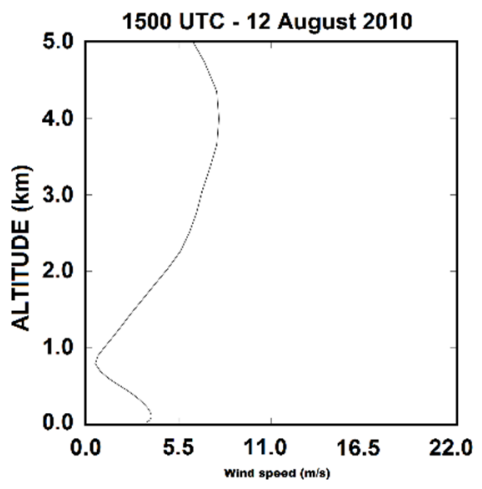

(c)

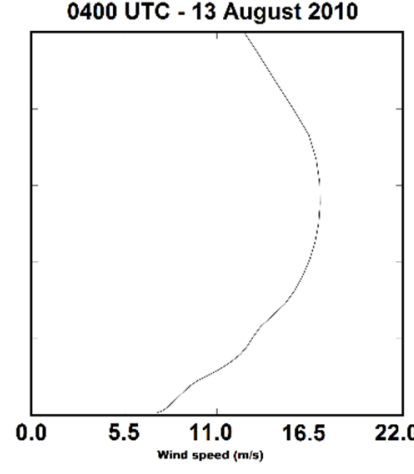

(d)

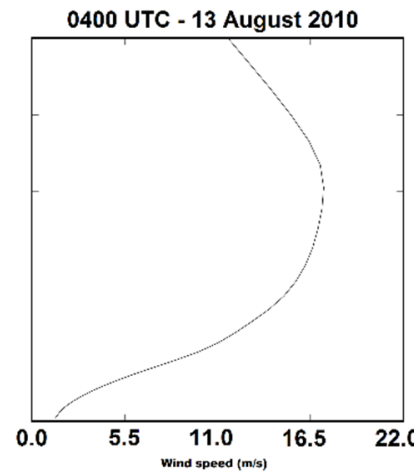

(e)

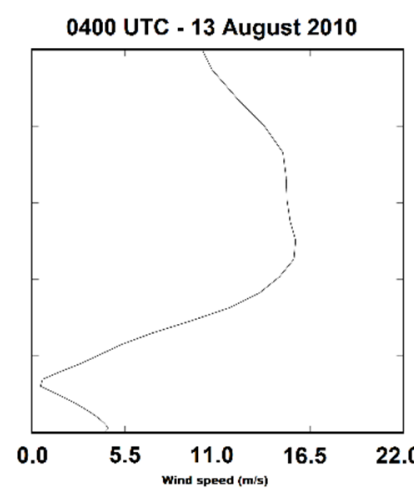

(f)

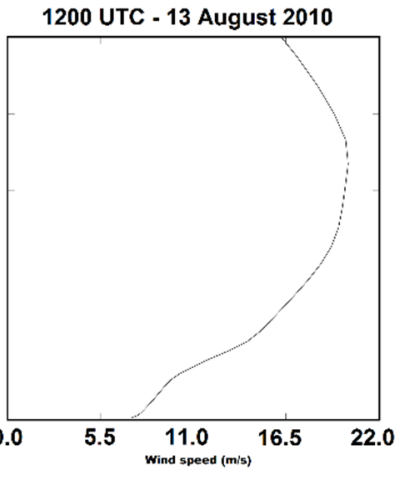

(g)

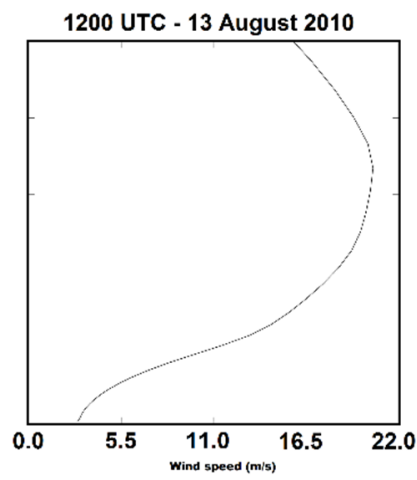

(h)

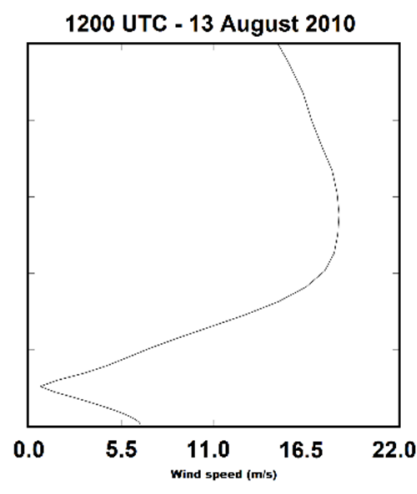

(i)

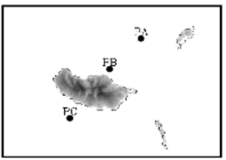

Figure 7. Vertical profile of horizontal wind velocity simulated at 500m resolution for Period 1. (a,d,g) for Point A (latitude: 33.05, longitude: -16.65), whereas (b,e,h) for Point B (latitude: 32.87, longitude: -16.87), and (c,f,i) for Point C (latitude: 32.58, longitude: -17.15).

As a consequence of such circulation affecting the island, weak wind gusts were simulated over a large part of Madeira $(<15 \mathrm{~m} / \mathrm{s})$ during the afternoon of 12 August (Figure 8a). The condition intensified overnight (Figure $8 \mathbf{b}$ ) with wind gusts higher than $22 \mathrm{~m} / \mathrm{s}$ in the mountains top. The situation remains during the second day with wind gusts higher than $20 \mathrm{~m} / \mathrm{s}$ over the highlands in the central part of the island (Figure 8c). Such a condition favoured fire spread in the Madeira highlands over the eastern peak (see Figure 3a). Additionally, the figures reveal the establishment of two low-level tip-jets, near the east and west flanks of the island, which is a frequent feature during the summer atmospheric flow over Madeira Island [62]. The figure also shows vectors representing the 
wind at $500 \mathrm{~m}$ altitude, which indicate that below $1 \mathrm{~km}$ altitude the north-easterly flow was forced to go around the island. It was determined there was a decrease in wind intensity as the airflow approached the island, extending over the ocean near to the northern coastal zone (smallest arrows). The mountain effect on the airflow can also be seen over the ocean to the south-westward corresponding to a decrease in wind intensity and the inversion of its direction close to the surface, due to the development of the sea breeze, as seen in Figure $7 \mathrm{c}, \mathrm{f}, \mathrm{i}$. These effects at the lowest levels were maintained throughout the period, and even followed slight changes in flow direction.

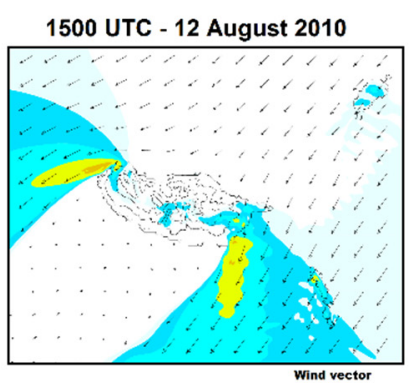

(a) $\quad 0.228 \mathrm{~m} / \mathrm{s} \quad 15.4 \mathrm{~m} / \mathrm{s}$

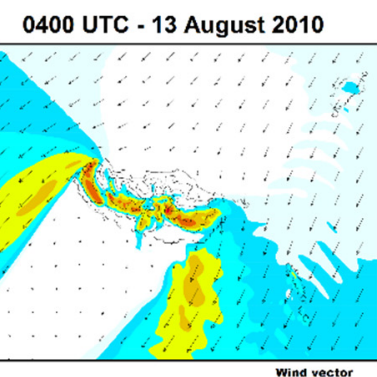

(b)

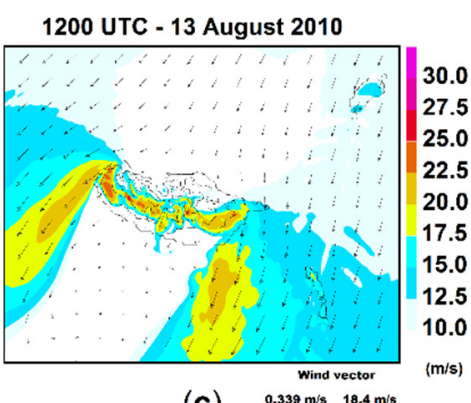

(C) $\quad 0.339 \mathrm{~m} / \mathrm{s} \quad 18.4 \mathrm{~m} / \mathrm{s}$

Figure 8. (a)-(c) represent wind gusts at $10 \mathrm{~m}$ simulated by the inner domain during Period 1 (filled contours). The line contours over the island represent the elevation in each $500 \mathrm{~m}$ altitude. The arrows represent the mean wind at $500 \mathrm{~m}$ altitude $(\mathrm{m} / \mathrm{s})$.

Figure 9 a show the air temperature field at $2 \mathrm{~m}$ with values above $32{ }^{\circ} \mathrm{C}$ along the southern slopes and above $34{ }^{\circ} \mathrm{C}$ in other areas, namely where the wildfires occurred. Notice that the atmospheric model does not take fire effects into account. At night, temperatures above $26^{\circ} \mathrm{C}$ were simulated on the southern slopes, namely in the landscapes located at the middle elevations (Figure $9 \mathrm{~b}$ ). On the second day, the temperatures were milder than the first day, with maximums on the southern slopes around $32{ }^{\circ} \mathrm{C}$ (Figure 9c). The squares represent the temperature at the meteorological stations. The simple comparison shows that the model well represents the temperature near the surface, even with some punctual overestimation (Figure 9c).

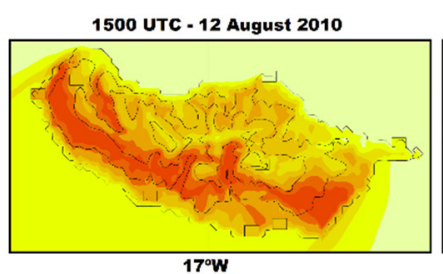

(a)

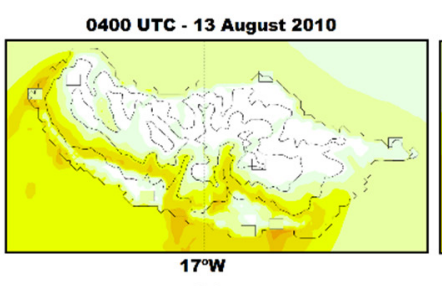

(b)

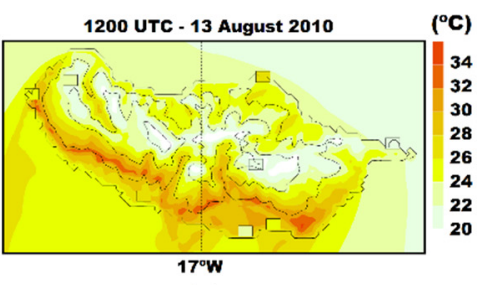

(c)

Figure 9. (a)-(c) represent air temperature at $2 \mathrm{~m}$ simulated at $500 \mathrm{~m}$ resolution during the Period 1. The line contours over the island represent the elevation in each $500 \mathrm{~m}$ altitude. The squares represent the observations at the meteorological stations.

Concerning the relative humidity at $2 \mathrm{~m}$ (Figure 10), values below $20 \%$ were determined over a large part of the island on 12 August (Figure 10a), decreasing to $~ 15 \%$ near Funchal (see Figure 1a for the location). The relative humidity remained low on the southern slopes at night, showing values below $25 \%$ in most parts of the midlands (Figure 10b). On 13 August (Figure 10c), values of around 20\% were simulated over the central part of the island, with some minimums around $15 \%$ in the southern slope. The comparison with the meteorological stations show a good representation (Figure 10a,b), with an underestimation of the relative humidity near the southern coast in Figure 10c. 
1500 UTC - 12 August 2010

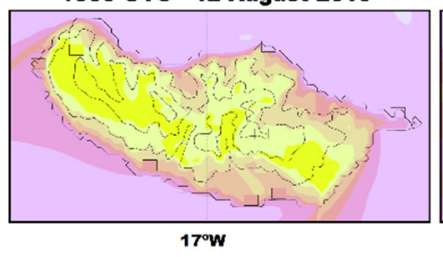

(a)
0400 UTC - 13 August 2010

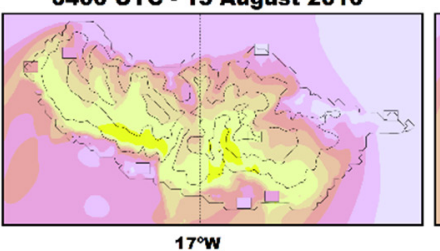

(b)
1200 UTC - 13 August 2010

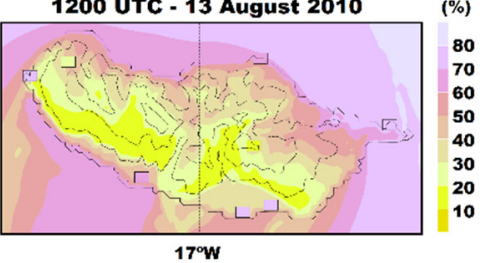

(c)

Figure 10. (a)-(c) represent relative humidity at $2 \mathrm{~m}$ simulated at $500 \mathrm{~m}$ resolution during the Period 1. The line contours over the island represent the elevation in each $500 \mathrm{~m}$ altitude. The squares represent the observations at the meteorological stations.

Figure 11 shows a vertical cross-section (displayed in Figure 11b) of the vertical wind speed over the eastern part of the island. Figure 11a indicates that the dominant effect of the island in deviating the airflow was not the unique effect and, around $1 \mathrm{~km}$ altitude, the airflow was forced to go over the island through the highlands of the northern slopes. This effect reinforced the noteworthy intense downward motion in the southern slopes and the effect of the gravity waves extending southward.

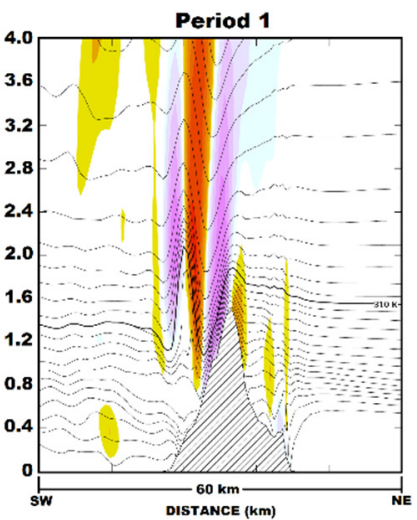

(a)

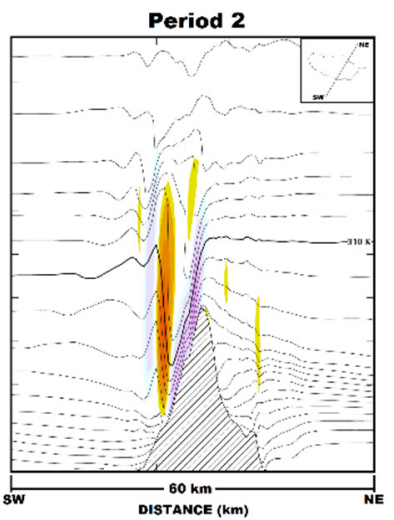

(b)

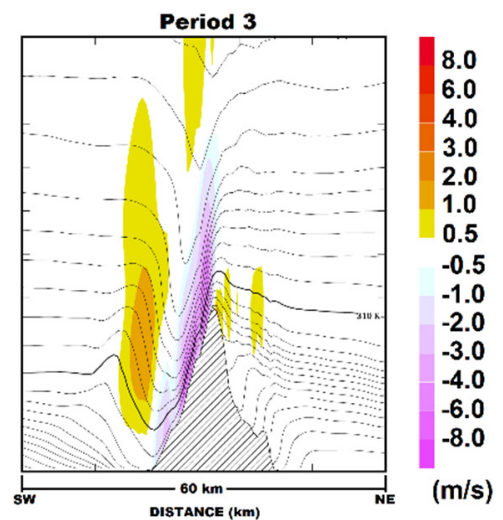

(c)

Figure 11. South-west to north-east vertical cross section of vertical velocity (coloured areas) crossing the eastern part of the island and potential temperature (black lines) (a) 0400 UTC-13 August 2010, (b) 0000 UTC-19 July 2012, and (c) 0000 UTC-09 August 2016. The localization of the cross section is indicated in the inner figure in (b).

\subsubsection{Period 2: 18 and 19 July 2012}

Figure 12 displays the vertical profile of the wind module at three points over the ocean (Points A, B and C at the bottom of the Figure 7) for the selected hours of Period 2. The maximum wind speed of almost $11 \mathrm{~m} / \mathrm{s}$ was simulated between $500 \mathrm{~m}$ and $1500 \mathrm{~m}$ altitude during the afternoon of the 18 July (Figure 12a). Close to the northern part of the island, still over the ocean (Point B), the vertical profile of the wind module shows a decrease in the intensity of the airflow as it approached the island, with winds of $2.5 \mathrm{~m} / \mathrm{s}$ below $500 \mathrm{~m}$ altitude (Figure 12b). There was a slight intensification of this condition, with winds of $11 \mathrm{~m} / \mathrm{s}$ at $800 \mathrm{~m}$ altitude, at 0000 UTC (Figure 12d). At Point B, winds reached a minimum lesser than $2.5 \mathrm{~m} / \mathrm{s}$ near the surface (Figure 12e). On 19 July, the wind intensity affecting the island decreased and during the afternoon (Figure 12g); for example, the maximum wind intensity at $600 \mathrm{~m}$ was below $10 \mathrm{~m} / \mathrm{s}$. Close to the island (Point B; Figure 12h), a decrease of airflow intensity was noticed, mainly near the surface. 


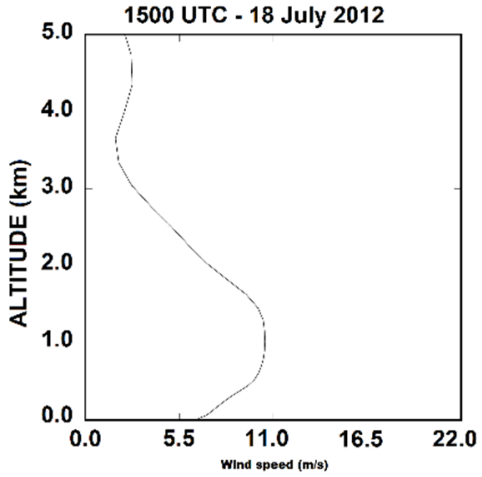

(a)

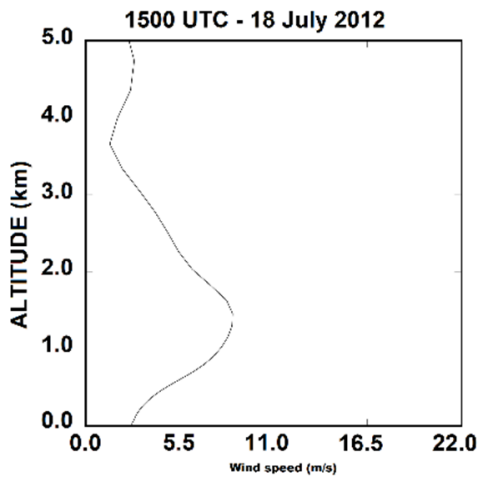

(b)

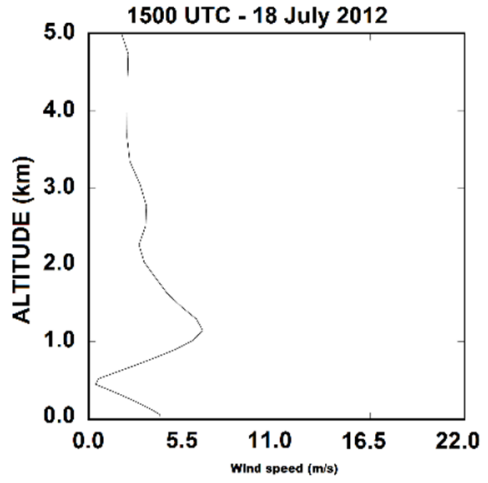

(c)

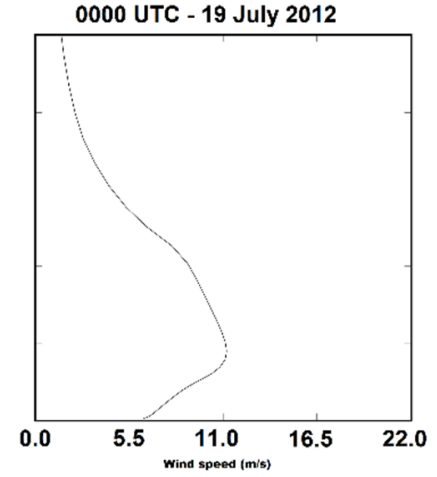

(d)

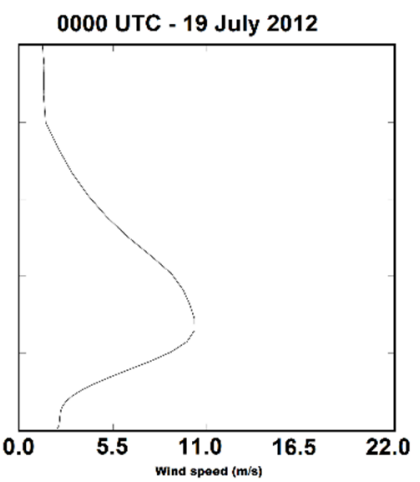

(e)

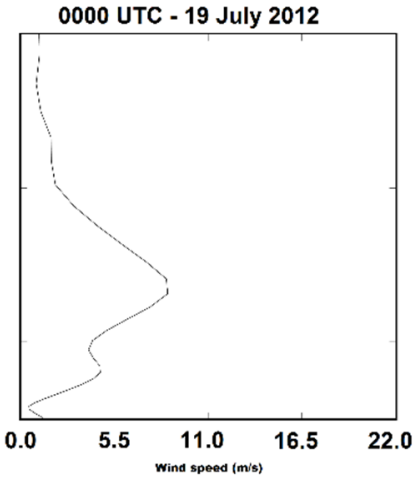

(f)

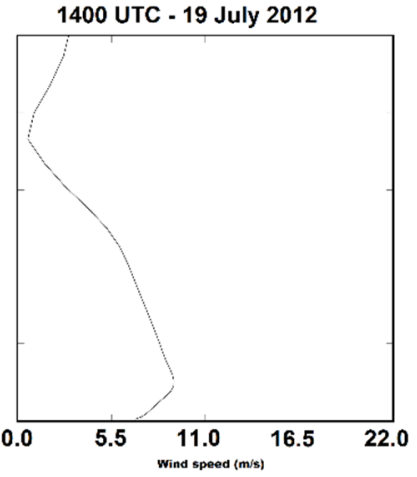

(g)

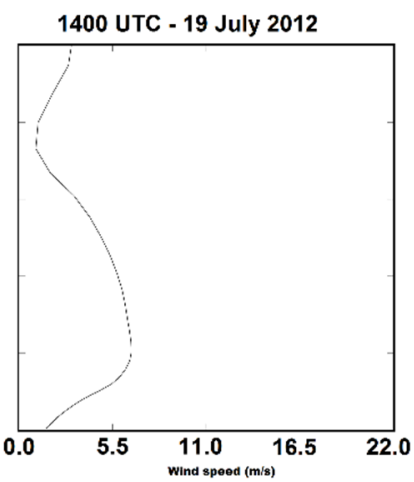

(h)

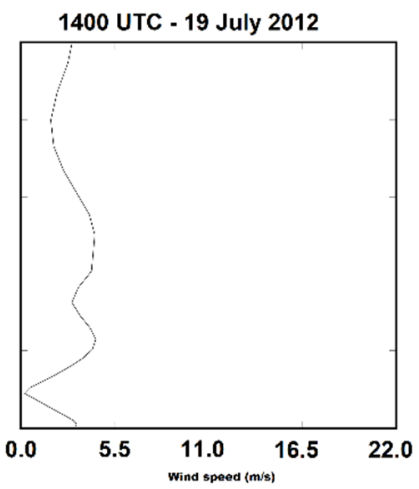

(i)

Figure 12. As Figure 7, but for Period 2.

As in Period 1, Figure 12c,i together with the vertical profile of horizontal wind directions (Figure S1a,b of the Supplementary Material) show the existence of a sea breeze circulation during the afternoon.

The simulated wind gusts at $10 \mathrm{~m}$ reached values around $15 \mathrm{~m} / \mathrm{s}$ at the top of the island in the central area (Figure 13a) and were slightly stronger at 0000 UTC (Figure 13b). The model revealed a gradual decreasing of the wind gusts during 19 July (Figure 13c). However, it is noteworthy that the model simulated wind gusts above $17 \mathrm{~m} / \mathrm{s}$ in the eastern and especially in the western regions, associated with the low-level tip-jets. These relatively higher gusts occurred in the areas most affected by wildfires (see Figure 3b). Figure 13 also shows that the airflow reaching the island was predominantly from the north-east along the period throughout the lower troposphere. In this case, the mountain effect was more evident in the lowest levels where the airflow was deviated by the island (Figure 13). The decreasing of the airflow as it approached and go around the island was seen over the ocean along the northern coastal region. Concerning the vertical speed, Figure 11b shows relatively strong downward motion in the southern slopes and upward motion in 
the northern ones above $800 \mathrm{~m}$ altitude, also indicating that the airflow tends to go around the island at the lowest levels.

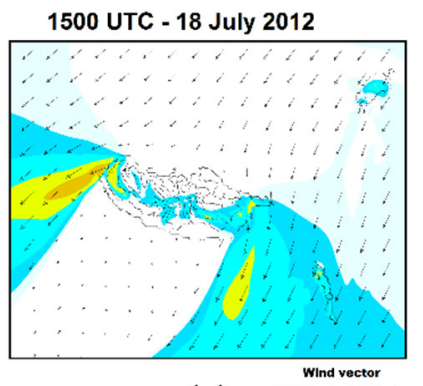

(a) $\begin{gathered}\text { Wind vector } \\ 0.124 \mathrm{~m} / \mathrm{s} \quad 16.3 \mathrm{~m} / \mathrm{s}\end{gathered}$

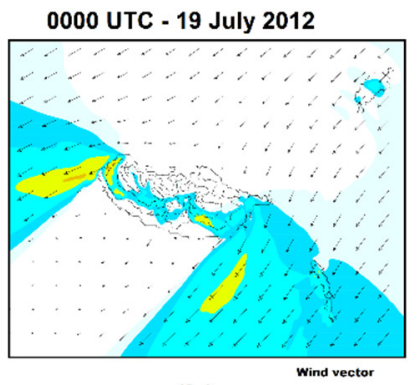

(b) $\begin{aligned} & 0.398 \mathrm{~m} / \mathrm{s} \\ & \text { Minimum } 16.1 \mathrm{~m} / \mathrm{s} \\ & \text { Maximum }\end{aligned}$

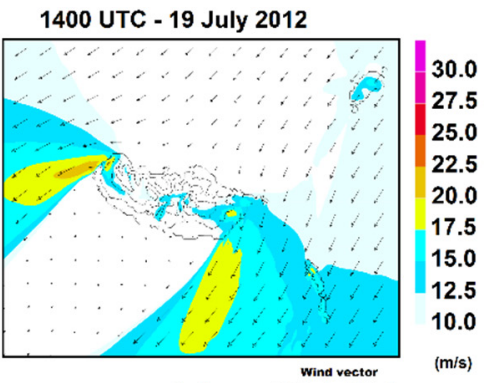

(C) $\begin{array}{ll}0.658 \mathrm{~m} / \mathrm{s} & 15.5 \mathrm{~m} / \mathrm{s} \\ \text { Minimum } & \text { Maximum }\end{array}$

Figure 13. As Figure 8, but for Period 2.

Figure 14 a shows air temperatures at $2 \mathrm{~m}$ above $30{ }^{\circ} \mathrm{C}$ on the southern slopes, as well as maximum temperatures above $34{ }^{\circ} \mathrm{C}$ in the south-eastern part of the island. At night, milder temperatures around $25^{\circ} \mathrm{C}$ were simulated in the highlands of the southern slopes, as well as $30^{\circ} \mathrm{C}$ in the south-eastern foothill of the island (Figure 14b). In the early afternoon, at $1400 \mathrm{UTC}$, temperatures above $30^{\circ} \mathrm{C}$ and a maximum of $34{ }^{\circ} \mathrm{C}$ in the south-eastern part of the island were simulated, but in a lesser extension (Figure 14c). The model well represents the spatial distribution of the temperature near surface when compared with the observations available during the period.

1500 UTC - 18 July 2012

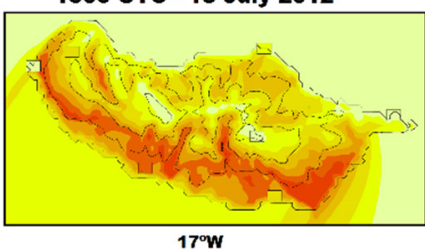

(a)
0000 UTC - 19 July 2012

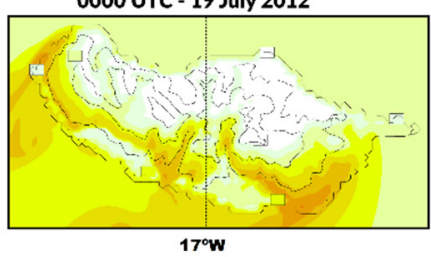

(b)
1400 UTC - 19 July 2012

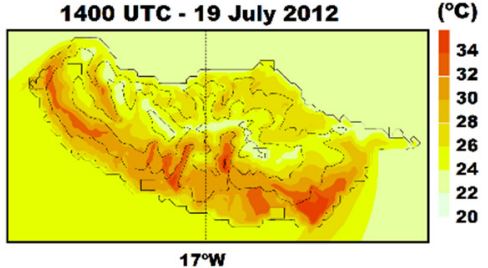

(c)

Figure 14. As Figure 9, but for Period 2.

For the relative humidity field at $2 \mathrm{~m}$, we obtained values below $30 \%$ over a large part of the southern slopes (Figure 15a), with no changes during the night (Figure 15b). Figure $15 \mathrm{c}$ shows a decrease of relative humidity in the second day, with values below $20 \%$ in the central part of the island and a minimum lesser than $10 \%$ in the south-eastern region. In general, the comparisons with observations show that the model well represents the relative humidity field near surface.

1500 UTC - 18 July 2012

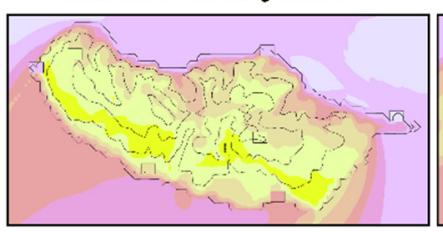

$17^{\circ} \mathrm{W}$

(a)
0000 UTC - 19 July 2012

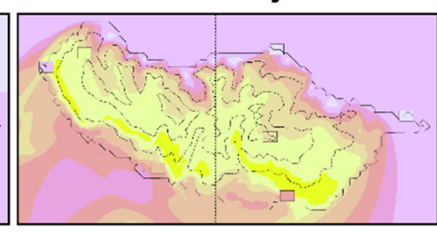

(b)

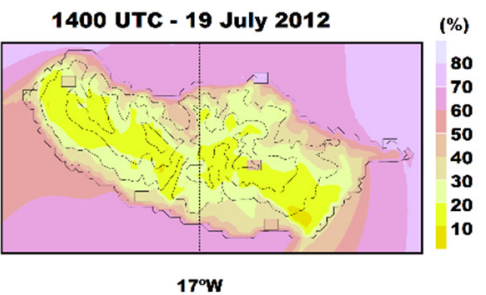

(c)

Figure 15. As Figure 10, but for Period 2.

\subsubsection{Period 3: 08 to 10 August 2016}

In Figure 16a, the vertical wind profile at Point A shows that the airflow approaching the island reached an intensity above $15 \mathrm{~m} / \mathrm{s}$ on 08 August. The results show that the winds start to decrease in intensity from the morning of 09 August. The wind intensity around $12 \mathrm{~m} / \mathrm{s}$ were verified in the afternoon at $1000 \mathrm{~m}$ altitude (Figure 16d), and decreasing 
in intensity and altitude on 10 August (Figure $16 \mathrm{~g}$ ), showing wind speed of $10 \mathrm{~m} / \mathrm{s}$ in the afternoon and below $500 \mathrm{~m}$ altitude (Figure 16g). At Point B, the mountain effect in lowest levels of the wind field is evident in all the vertical profiles during the entire period, with weak winds being simulated up to $500 \mathrm{~m}$ altitude (Figure 16b,e,h), but with no effect or even a slight increase between 1 and $2 \mathrm{~km}$ above sea surface. Contrary to what was identified in Periods 1 and 2, Figure 16c,f,i do not contain a signature of the occurrence of a local sea breeze near the south coast, certainly linked to the fact that the mountain downward flow extends along the entire slope to near the coast (Figure 11c).

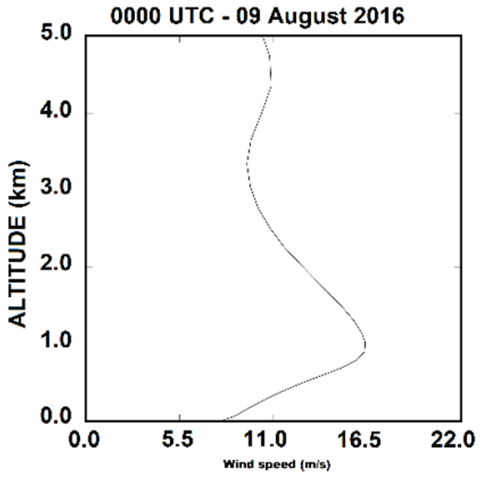

(a)

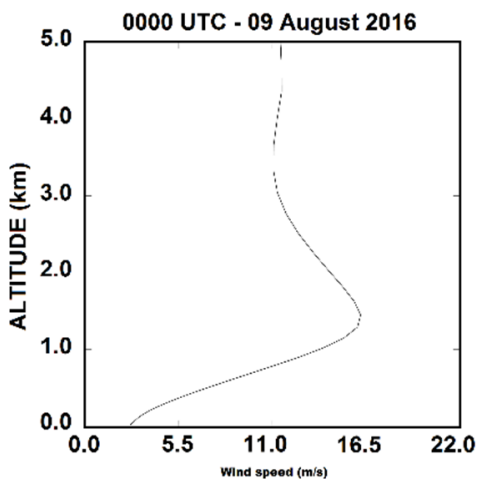

(b)

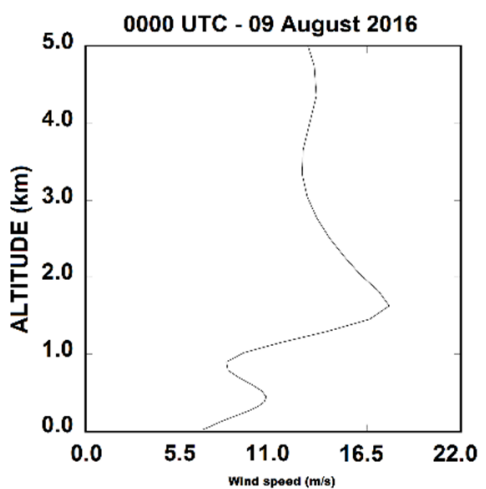

(c)

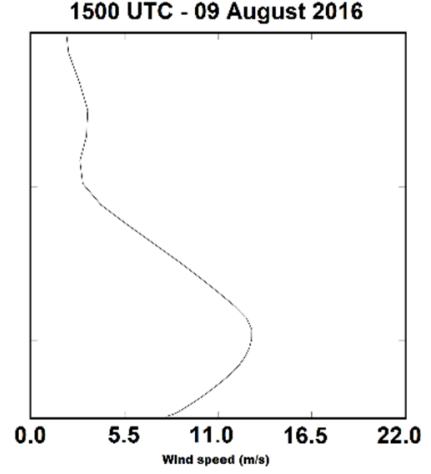

(d)

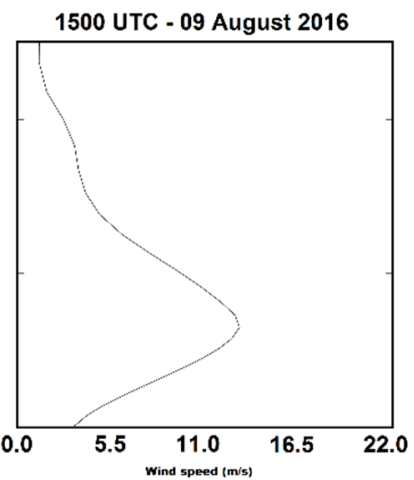

(e)

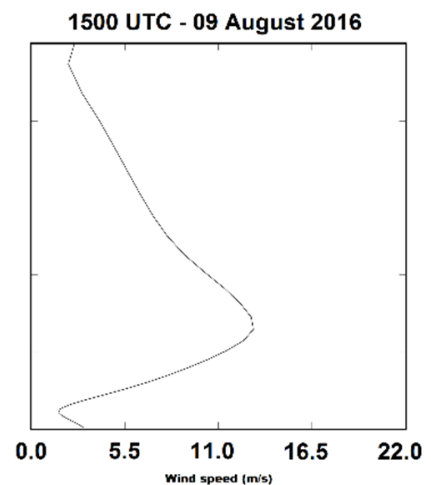

(f)

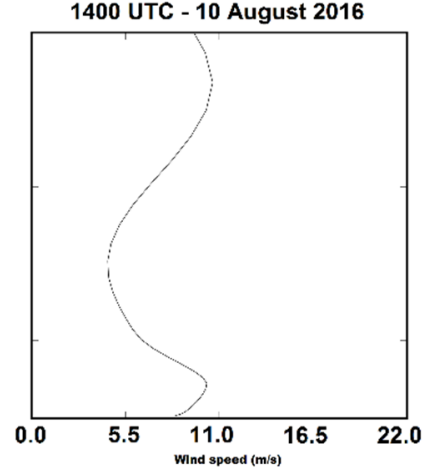

(g)

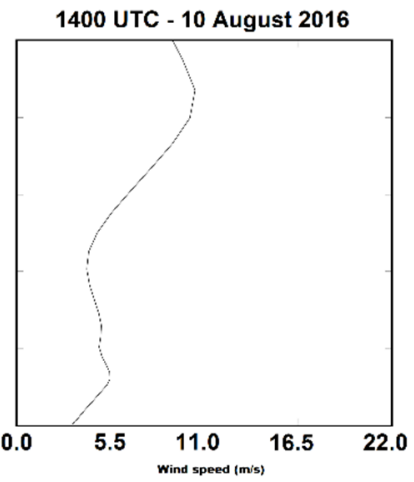

(h)

1400 UTC - 10 August 2016

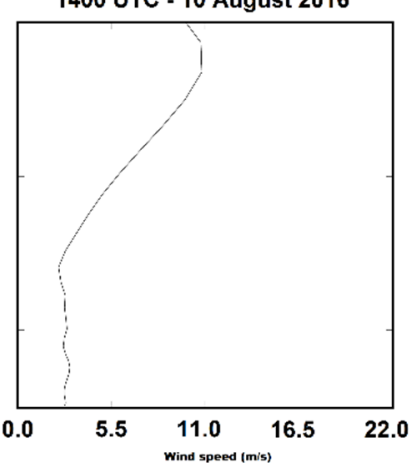

(i)

Figure 16. As Figure 7, but for Period 3.

The wind gusts at $10 \mathrm{~m}$ are shown in Figure 17a-f. Figure $17 \mathrm{a}-\mathrm{c}$ show extreme gusts over the island with speeds above $25 \mathrm{~m} / \mathrm{s}$ and maximum above $30 \mathrm{~m} / \mathrm{s}$, mainly in the central region and the south-eastern part of the island. Maximums exceeding $25 \mathrm{~m} / \mathrm{s}$ were observed in the southern slopes near Funchal where one of the large fires occurred (See Figure 3c,d). Wind loses intensity along the day (Figure 17d,e); however, intense wind gusts were still simulated in the west and south-eastern parts of the island. During 
10 August, there were no records of significant wind gusts over the island, except in the extreme west and east of the island where a punctual maximum above $20 \mathrm{~m} / \mathrm{s}$ was simulated inside the low-level western jet (Figure 17e,f). Figure 17 shows that the airflow affecting the island at lower troposphere varies between north-easterly and almost easterly along the period. In this case, Figure 11c shows that the downward motion created by orography was more intense than the upward motion simulated in the top of the island which extends up to the lowlands of the south-eastern region.

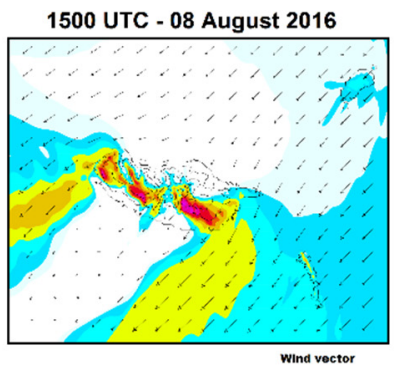

(a) $\begin{gathered}0.561 \mathrm{~m} / \mathrm{s} \\ 20.6 \mathrm{mms} \\ \text { mininum max matimum }\end{gathered}$

1500 UTC - 09 August 2016

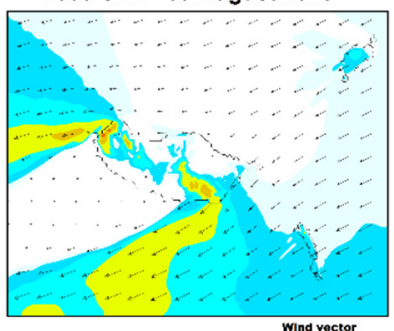

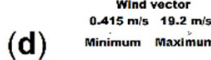

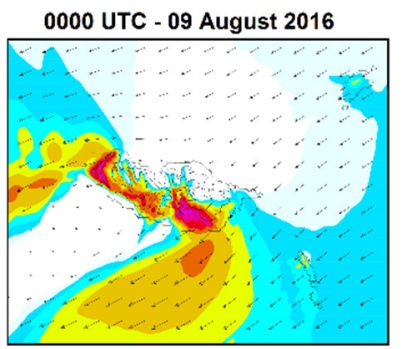

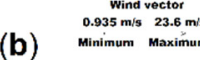

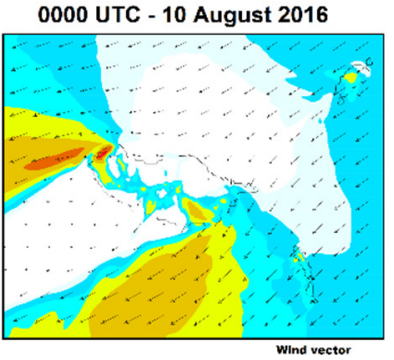

(e)

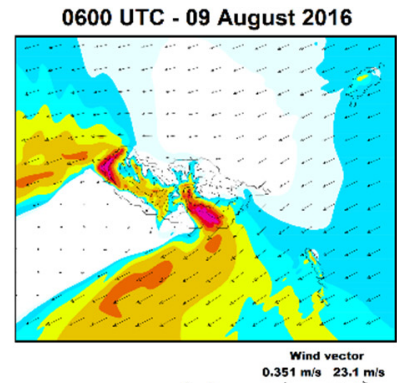

(c)

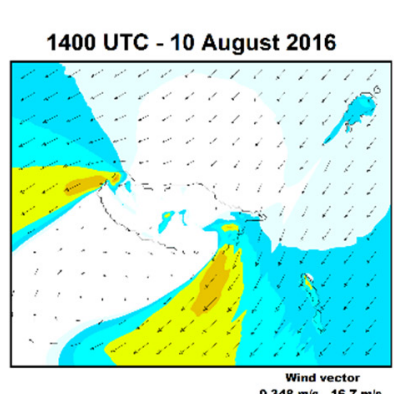

(f)

Figure 17. As Figure 8, but for Period 3.

The same behaviour was shown by [63] using AROME (Application of Research to Operations at Mesoscale) model forecasts for the same day at Madeira Island. The authors argued that the strong downward winds in the layer below $4 \mathrm{~km}$ were caused by the vertically propagating mountain wave, which may be classified as moderate by the International Civil Aviation Organization (ICAO) guidelines.

On 08 August, temperatures above $34{ }^{\circ} \mathrm{C}$ were simulated near the surface in the lowlands on the southern slopes (Figure 18a), and still above $32{ }^{\circ} \mathrm{C}$ during the night (Figure 18b). In the following day, there was an intensification of this hot condition (Figure 18c). On 10 August, the simulated temperatures were lower than in the previous days, around $30^{\circ} \mathrm{C}$ on the southern slopes during the afternoon and below $25^{\circ} \mathrm{C}$ in the early night (not shown). The simulated air temperature is close to the observed ones, except at midnight, when the model tends to overestimate the temperature at the south coast.

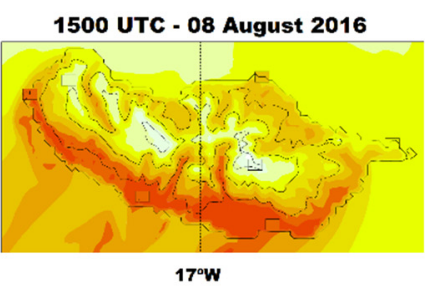

(a)

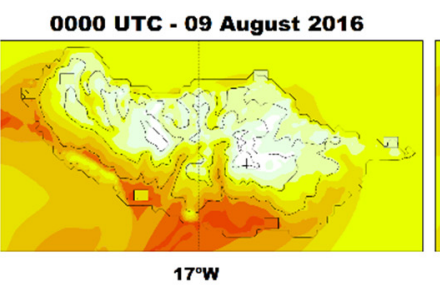

(b)

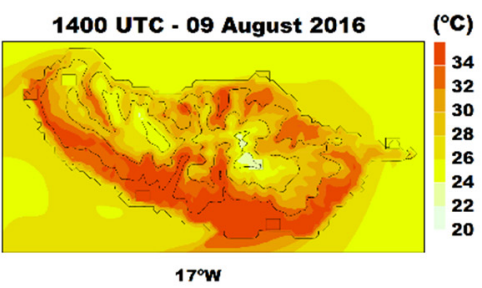

(c)

Figure 18. As Figure 9, but for Period 3. 
Relative humidity below $30 \%$ on the southern slopes was simulated in the afternoon of 08 August, with minimums below 20\% (Figure 19a). The decrease in humidity at night was intensified by the model with values below $15 \%$ in the southern half of the island, which is not shown by observations (Figure 19b). There was a slight increase in the relative humidity throughout the day, but not exceeding $25 \%$ in the southern slopes (Figure 19c). At this moment, the model well represented the spatial distribution of the relative humidity over the island. The increase in the relative humidity values over the island gradually occurred along the rest of the period, with the minimums still simulated along the central part of the island (Figure 19d).

1500 UTC - 08 August 2016

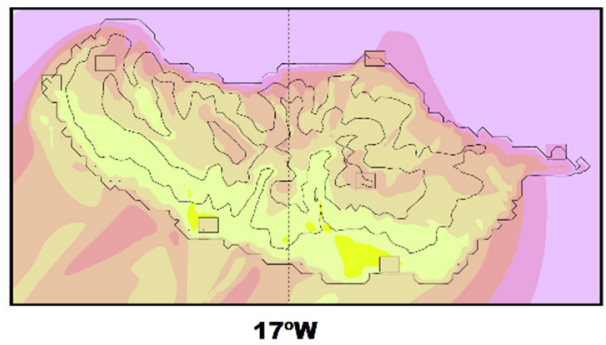

(a)

1400 UTC - 09 August 2016

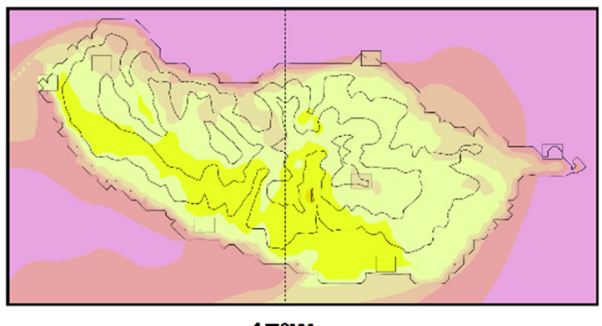

(c)
0600 UTC - 09 August 2016

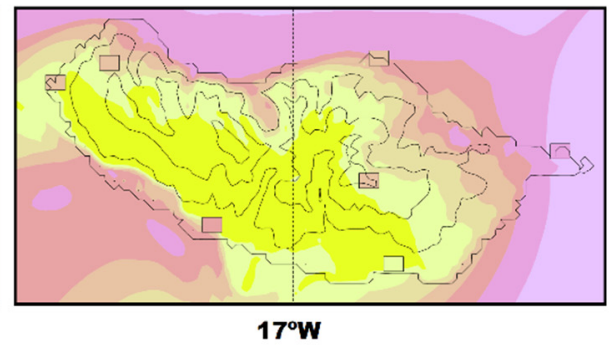

(b)

1400 UTC - 10 August 2016

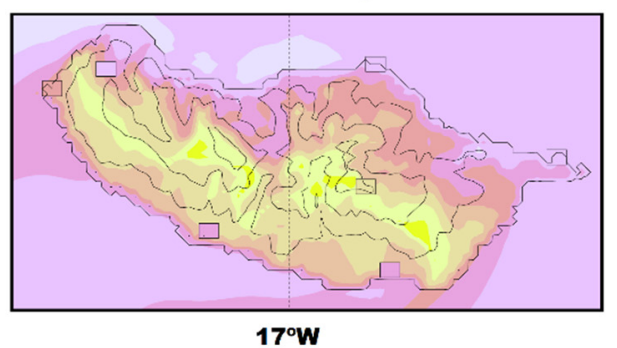

(d)
(\%)

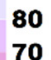

70

60
50

40

30

20

10

Figure 19. As Figure 10, but for Period 3.

\section{Summary and Conclusions}

A set of numerical simulations have been used to explore the atmospheric conditions during three periods of large fire events in Madeira Island. The summer season, characterized by low precipitation over the island [35], is a critical fire weather period, and the atmospheric conditions jointly with the complex local terrain are the main factors increasing the fire danger and probably influencing the fuel availability, namely in the southern slopes.

Concerning the synoptic situation, the Azores Anticyclone was the typical synoptic system over the North Atlantic Ocean inducing the north-easterly airflow towards the island in its coastal zones (eastern side). As it remains almost stationary, the fair weather was maintained over the region for several days.

The simulations showed that the atmospheric conditions in the southern slopes are driven by the local orography, which intensified the effects of typical anticyclone conditions prevailing over the North Atlantic Ocean. Under a north-easterly flow at lower levels, the island shape and orientation may produce a mountain blocking and orographic lifting or flow deflection effects depending on the wind vertical profile [38]. However, the orographic lifting mechanism was not predominant in this study and the relatively weak winds at lower levels were deviated as they approached the island. In general, the winds slow down in the northern region over the ocean and between the ocean surface and the top of the island. Such a configuration, in which the air is forced to flow over the top of the island and around at the lowest atmospheric levels, is consistent with the conceptual models 
of stably stratified flows crossing three-dimensional obstacles presented by [64] and for situations of slightly faster winds or weaker stability [65]. In the third episode, our results showed an intense downward motion reaching the Madeira foothills in the southern slopes and eastern part of the island. Such a situation indicates that the downslope motion can be associated with a mechanically driven mechanism. Such a mechanism involves the upstream blocking of low-level flow by a mountain barrier, with drier air flowing down to replace it in the lee of the mountains [66]. In addition, as the drier air from above descends the lee slopes it is warmed by adiabatic compression.

Over the island, the downward motion created by the local orography at the southern slopes was evident from the simulations, which was represented through the wind gusts field at $10 \mathrm{~m}$. The intense wind gusts at the surface in the southern slopes, namely in the highlands, was observed in all periods, and mainly during the night-time (corresponding to the maximum fire daily expansion showed in Table 1). In the first two episodes, the downward motion was restricted to the highlands up to the southern half-slope, while closer to the coast the wind blew from the sea, countering the fire spread to lower altitudes.

The combined effect of terrain and atmospheric conditions increased fire danger by leading the maximum temperatures above $35^{\circ} \mathrm{C}$ and relative humidity around $15 \%$, exacerbated by intense gusts, in particular in the third episode. In this last episode, the first day was characterised by extreme gusts in the southern slopes not thwarted by the sea breeze, produced by the intense north-easterly winds that affected the top of the island. This situation favoured a high temperature during the afternoon, as well as overnight temperatures above $30^{\circ} \mathrm{C}$. The warm night probably influenced the fuel moisture, as the relative humidity dropped from levels below $25 \%$ in the afternoon to below $15 \%$ along the night. The model also showed the generation of local downslope winds, which contribute to intensify fire danger, increasing air temperature, reducing the relative humidity and driving the fire spread. In general, the model represented well the temperature and relative humidity at surface, despite some local over- or underestimation.

The evolution of the fires was driven from a combination of factors that led to an enhanced fire danger by also favouring fuel availability. The north-easterly winds are drier due to the orographic effects, and the warm flow gradually decreased fuel moisture. Such environment is a strong indicator of potentially extreme fire behaviour. In addition, the strong wind gusts and the rugged terrain challenges fire suppression, allowing fire to expand over large areas in short time periods.

The high-resolution simulations showed fire-prone areas over the island and weather patterns related to high daytime temperatures and sometimes overnight, low humidity, and strong wind gusts that favour fire growth. The absence of precipitation is another factor contributing for this propitious condition to fires over the island. It is noteworthy that sometimes the highest fire danger, based on these elementary meteorological variables, was identified near urban areas in the southern foothills, namely in Funchal city, where one of the August 2016 extreme fire events took place. All of these large fire events analysed in our study showed very high rates of expansion over short periods of time, which, cumulatively with the topographic roughness, challenged the suppression capacity installed on the island and threatened a high number of natural and man-made values.

Forest fires are becoming more and more common and destructive, with several factors affecting their behaviour. Identifying fire weather conditions exacerbated by local effects at the surface may be useful for specific regions, mainly for the inhabitants of forested islands, where fire danger can be directly linked to these factors. The study shows an alternative that can identify fire danger and anticipate fire behaviour in Madeira Island. However, the study highlighted just two of the three basic parameters associated with fire behaviour, i.e., the meteorological aspects and terrain effects enhancing fire danger. Therefore, an analysis also including the spatial distribution of fuel types and structure must be conducted in the future, as well as studies addressing the fire danger during the fire season. Additionally, the interactions between fire and atmospheric circulations must also be taken into account. 
In summary, the results found in our study may support strategies for reducing the risk posed by the fire danger created by meteorological and terrain aspects. The use of high-resolution simulations is able to indicate the regions more proneness to large fires, namely those affected by the highest near surface temperatures and lowest values of relative humidity. It is suggested for future works the consideration of vegetation characteristics to develop well-suited strategies to prevent the occurrence of large fires and to well suppress fires in these conditions, i.e., through local systems able to compute scenarios of fire growth under a fire forecast context. Such a framework could support the development of better fire management practices, as well as promoting a sustainable development.

Supplementary Materials: The following are available online at https:/ / www.mdpi.com/article/ 10.3390 /atmos12070827/s1, Figure S1: Vertical profile of horizontal wind velocity simulated at $500 \mathrm{~m}$ resolution and wind direction: (a) 1500 UTC-18th July 2012, (b) 1400 UTC—19th July 2012.

Author Contributions: Conceptualization, F.T.C. and R.S.; methodology, F.T.C. and R.S.; software, F.T.C. and R.S.; formal analysis, F.T.C. and R.S.; investigation, F.T.C.; resources, R.S., N.G.; data curation, F.T.C., N.G.; writing—original draft preparation, F.T.C.; writing—review and editing, R.S., N.G.; visualization, F.T.C., N.G.; supervision, R.S.; project administration, R.S.; funding acquisition, R.S. All authors have read and agreed to the published version of the manuscript.

Funding: This research was funded by the European Union through the European Regional Devel opment Fund in the framework of the Interreg V A Spain-Portugal program (POCTEP) through the CILIFO project (Ref.: 0753_CILIFO_5_E), and also by national funds through FCT-Foundation for Science and Technology, I.P. under the PyroC.pt project (Refs. PCIF/MPG/0175/2019) and ICT project (Refs. UIDB/04683/2020 and UIDP/04683/2020).

Informed Consent Statement: Not applicable.

Acknowledgments: We want to thank Paulo Fernandes (University of Trás-os-Montes e Alto Douro; Collaborative Laboratory ForestWISE; Independent Technical Observatory for Rural Fires) for making available the annual burned areas on Madeira Island and for the spatial distribution of the burned areas. The authors are grateful to the Portuguese meteorological service (IPMA), for providing meteorological data and to the European Centre for Medium-Range Weather Forecasts (ECMWF), for the provided meteorological analysis.

Conflicts of Interest: The authors declare no conflict of interest.

\section{References}

1. Roe, G.H. Orographic precipitation. Annu. Rev. Earth Planet. Sci. 2005, 33, 645-671. [CrossRef]

2. Houze, R.A. Orographic effects on precipitating clouds. Rev. Geophys. 2012, 50, RG1001. [CrossRef]

3. Sharples, J.J. An overview of mountain meteorological effects relevant to fire behaviour and bushfire risk. Int. J. Wildland Fire 2009, 18, 737-754. [CrossRef]

4. Coen, J.L.; Schroeder, W.; Quayle, B. The Generation and Forecast of Extreme Winds during the Origin and Progression of the 2017 Tubbs Fire. Atmosphere 2018, 9, 462. [CrossRef]

5. Brewer, M.J.; Clements, C.B. The 2018 Camp Fire: Meteorological Analysis Using In Situ Observations and Numerical Simulations. Atmosphere 2020, 11, 47. [CrossRef]

6. Coen, J.L.; Schroeder, W. The High Park fire: Coupled weather-wildland fire model simulation of a windstorm-driven wildfire in Colorado's Front Range. J. Geophys. Res. Atmos. 2015, 120, 131-146. [CrossRef]

7. Dowdy, A.J.; Ye, H.; Pepler, A. Future changes in extreme weather and pyroconvection risk factors for Australian wildfires. Sci. Rep. 2019, 9, 10073. [CrossRef] [PubMed]

8. Di Virgilio, G.; Evans, J.P.; Blake, S.A.P.; Armstrong, M.; Dowdy, A.J.; Sharples, J.; McRae, R. Climate change increases the potential for extreme wildfires. Geophys. Res. Lett. 2019, 46, 8517-8526. [CrossRef]

9. Dennison, P.E.; Brewer, S.C.; Arnold, J.D.; Moritz, M.A. Large wildfire trends in the western United States, 1984-2011. Geophys. Res. Lett. 2014, 41, 2928-2933. [CrossRef]

10. Abatzoglou, J.T.; Kolden, C.A. Relationships between climate and macroscale area burned in the western United States. Int. J. Wildland Fire 2013, 22, 1003-1020. [CrossRef]

11. Singleton, M.P.; Thode, A.E.; Sánchez Meador, A.J.; Iniguez, J.M. Increasing trends in high-severity fire in the southwestern USA from 1984 to 2015. For. Ecol. Manag. 2019, 433, 709-719. [CrossRef]

12. Fromm, M.D.; Lindsey, T.; Servranckx, R.; Yue, G.; Trickl, T.; Sica, R.; Doucet, P.; Godin-Beekmann, S. The Untold Story of Pyrocumulonimbus. Bull. Am. Meteorol. Soc. 2010, 91, 1193-1210. [CrossRef] 
13. Peterson, D.A.; Campbell, J.R.; Hyer, E.J. Wildfire-driven thunderstorms cause a volcano-like stratospheric injection of smoke. NPJ Clim. Atmos. Sci. 2018, 1, 30. [CrossRef] [PubMed]

14. Oliveira, T.M.; Barros, A.M.; Ager, A.A.; Fernandes, P.M. Assessing the effect of a fuel break network to reduce burnt area and wildfire risk transmission. Int. J. Wildland Fire 2016, 25, 619-632. [CrossRef]

15. Gonzalez-Olabarria, J.R.; Reynolds, K.M.; Larrañaga, A.; Garcia-Gonzalo, J.; Busquets, E.; Pique, M. Strategic and tactical planning to improve suppression efforts against large forest fires in the Catalonia region of Spain. For. Ecol. Manag. 2019, 432, 612-622. [CrossRef]

16. Finney, M. FARSITE: Fire Area Simulator-Model Development and Evaluation-Research Paper RMRS-RP-4 Revised; Technical Report; U.S. Department of Agriculture, Forest Service, Rocky Mountain Research Station: Ogden, UT, USA, 2004.

17. Morvan, D. Modeling the propagation of a wildfire through a Mediterranean shrub using a multiphase formulation. Combust. Flame 2004, 138, 199-210. [CrossRef]

18. Sullivan, A.L. Wildland surface fire spread modelling, 1990-2007. 1: Physical and quasi-physical models. Int. J. Wildland Fire 2019, 18, 349-368. [CrossRef]

19. Sullivan, A.L. Wildland surface fire spread modelling, 1990-2007. 2: Empirical and quasi-empirical models. Int. J. Wildland Fire 2009, 18, 369-386. [CrossRef]

20. Clark, T.; Jenkins, M.; Coen, J.; Packham, D. A Coupled Atmosphere Fire Model: Convective Feedback on Fire-Line Dynamics. J. Appl. Meteorol. 1996, 35, 875-901. [CrossRef]

21. Mandel, J.; Beezley, J.; Kochanski, A. Coupled atmosphere-wildland fire modeling with WRF 3.3 and SFIRE 2011. Geosci. Model Dev. 2011, 4, 591-610. [CrossRef]

22. Filippi, J.; Bosseur, F.; Pialat, X.; Santoni, P.; Strada, S.; Mari, C. Simulation of Coupled Fire/Atmosphere Interaction with the MesoNH-ForeFire Models. J. Combust. 2011, 2011, 1-13. [CrossRef]

23. Filippi, J.B.; Bosseur, F.; Mari, C.; Lac, C. Simulation of a large wildfire in a coupled fire-atmosphere model. Atmosphere 2018, 9, 218. [CrossRef]

24. Giannaros, T.M.; Kotroni, V.; Lagouvardos, K. IRIS-Rapid response fire spread forecasting system: Development, calibration and evaluation. Agric. For. Meteorol. 2019, 279, 107745. [CrossRef]

25. Cardil, A.; Monedero, S.; Silva, C.A.; Ramirez, J. Adjusting the rate of spread of fire simulations in real-time. Ecol. Model. 2019, 395, 39-44. [CrossRef]

26. Kartsios, S.; Karacostas, T.; Pytharoulis, I.; Dimitrakopoulos, A.P. Numerical investigation of atmosphere-fire interactions during high-impact wildland fire events in Greece. Atmos. Res. 2021, 247, 105253. [CrossRef]

27. Couto, F.T.; Iakunin, M.; Salgado, R.; Pinto, P.; Viegas, T.; Pinty, J.-P. Lightning modelling for the research of forest fire ignition in Portugal. Atmos. Res. 2020, 242, 104993. [CrossRef]

28. Ganteaume, A.; Syphard, A.D. Ignition Sources. In Encyclopedia of Wildfires and Wildland-Urban Interface (WUI) Fires; Manzello, S., Ed.; Springer: Cham, Switzerland, 2018. [CrossRef]

29. Kochtubajda, B.; Stewart, R.E.; Flannigan, M.D.; Bonsal, B.R.; Cuell, C.; Mooney, C.J. An Assessment of Surface and Atmospheric Conditions Associated with the Extreme 2014 Wildfire Season in Canada's Northwest Territories. Atmos. Ocean 2019, 57, 73-90. [CrossRef]

30. Couto, F.T.; Andrade, N.; Salgado, R.; Serra, J. Wildfire risk in Madeira island and the potential impacts on tourism. In Proceedings of the EGU General Assembly 2021, Online, 19-30 April 2021; p. EGU21-14575. [CrossRef]

31. CTI Report 2017. In Análise e Apuramento dos Factos Relativos aos Incêndios que Ocorreram em Pedrógão Grande, Castanheira de Pera, Ansião, Alvaiázere, Figueiró dos Vinhos, Arganil, Góis, Penela, Pampilhosa da Serra, Oleiros e Sertã, entre 17 e 24 de junho de 2017; Comissão Técnica Independente (CTI), Assembleia da República: Lisboa, Portugal, 2017; p. 296.

32. Adame, J.A.; Lope, L.; Hidalgo, P.J.; Sorribas, M.; Gutiérrez-Álvarez, I.; del Águila, A.; Saiz-Lopez, A.; Yela, M. Study of the exceptional meteorological conditions, trace gases and particulate matter measured during the 2017 forest fires in Doñana Natural Park, Spain. Sci. Total Environ. 2018, 645, 710-720. [CrossRef] [PubMed]

33. Guerreiro, J.; Fonseca, C.; Salgueiro, A.; Fernandes, P.; Lopez Iglésias, E.; de Neufville, R.; Mateus, F.; Castellnou Ribau, M.; Sande Silva, J.; Moura, J.M.; et al. Avaliação dos Incêndios Ocorridos Entre 14 e 16 de Outubro de 2017 em Portugal Continental. Relatório Final; CTI Report 2018; Comissão Técnica Independente (CTI), Assembleia da República: Lisboa, Portugal, 2018; p. 274.

34. Dowdy, A.J.; Mills, G.A. Atmospheric and fuel moisture characteristics associated with lightning-attributed fires. J. Appl. Meteorol. Climatol. 2012, 51, 2025-2037. [CrossRef]

35. Couto, F.T.; Salgado, R.; Costa, M.J.; Prior, V. Precipitation in the Madeira Island over a 10-year period and the meridional water vapour transport during the winter seasons. Int. J. Climatol. 2015, 35, 3748-3759. [CrossRef]

36. Couto, F.T.; Salgado, R.; Costa, M.J. Analysis of intense rainfall events on Madeira Island during the 2009/2010 winter. Nat. Hazards Earth Syst. Sci. 2012, 12, 2225-2240. [CrossRef]

37. Couto, F.T.; Ducrocq, V.; Salgado, R.; Costa, M.J. Numerical simulations of significant orographic precipitation in Madeira island. Atmos. Res. 2016, 169, 102-112. [CrossRef]

38. Couto, F.T.; Ducrocq, V.; Salgado, R.; Costa, M.J. Understanding significant precipitation in Madeira island using high-resolution numerical simulations of real cases. Q. J. R. Meteorol. Soc. 2017, 143, 251-264. [CrossRef]

39. Luna, T.; Rocha, A.; Carvalho, A.C.; Ferreira, J.A.; Sousa, J. Modelling the extreme precipitation event over Madeira Island on 20 February 2010. Nat. Hazards Earth Syst. Sci. 2011, 11, 2437-2452. [CrossRef] 
40. Lira, C.; Lousada, M.; Falcão, A.P.; Gonçalves, A.B.; Heleno, S.; Matias, M.; Pereira, M.J.; Pina, P.; Sousa, A.J.; Oliveira, R.; et al. The 20 February 2010 Madeira Island flash-floods: VHR satellite imagery processing in support of landslide inventory and sediment budget assessment. Nat. Hazards Earth Syst. Sci. 2013, 13, 709-719. [CrossRef]

41. Lopes, S.; Fragoso, M.; Lopes, A. Heavy Rainfall Events and Mass Movements in the Funchal Area (Madeira, Portugal): Spatial Analysis and Susceptibility Assessment. Atmosphere 2020, 11, 104. [CrossRef]

42. Prada, S.; da Silva, M. Fog precipitation on the Island of Madeira (Portugal). Environ. Geol. 2001, 41, 384-389. [CrossRef]

43. Prada, S.; Menezes, M.; Sequeira, D.; Figueira, C.; Oliveira, M. Fog precipitation and rainfall interception in the natural forests of Madeira Island (Portugal). Agric. For. Meteorol. 2009, 149, 1179-1187. [CrossRef]

44. Prada, S.; Prada, S.; Cruz, J.V.; Figueira, C. Using stable isotopes to characterize groundwater recharge sources in the volcanic island of Madeira. J. Hydrol. 2016, 536, 409-425. [CrossRef]

45. Fernandes, J.P.; Guiomar, N.; Gil, A. Strategies for conservation planning and management of terrestrial ecosystems in small islands (exemplified for the Macaronesian islands). Environ. Sci. Policy 2015, 51, 1-22. [CrossRef]

46. Oliveira, T. Secção Regional da Madeira da Ordem do Engenheiros. In Proceedings of the Technical Session on Wildfire Risk Management (Gestão de Risco de Incêndio Florestal), Funchal, Madeira, Portugal, 28 October 2016.

47. INCF Report (2016) Relatório Anual de áreas Ardidas e Incêndios Florestais em Portugal Continental, 2016. Instituto da Conservação da Natureza e das Florestas, I.P./Departamento de Gestão de Áreas Públicas e de Proteção Florestal, 2016; 50p, Available online: http:/ / www2.icnf.pt/portal/florestas/dfci/relat/rel-if/2016 (accessed on 16 December 2020).

48. Earth Observatory. Available online: https://earthobservatory.nasa.gov/images/45262/fires-in-madeira-portugal (accessed on 16 December 2020).

49. Earth Observatory. Available online: https://earthobservatory.nasa.gov/images/78603/madeira-wildfires (accessed on 16 December 2020).

50. EOSDIS-NASA. Available online: https://lance.modaps.eosdis.nasa.gov/cgi-bin/imagery/single.cgi?image=Madeira.A20162 23.1205.250m.jpg (accessed on 16 December 2020).

51. Earth Observatory. Available online: https://earthobservatory.nasa.gov/images/88590/fires-char-madeira (accessed on 16 December 2020).

52. Lafore, J.-P.; Stein, J.; Asencio, N.; Bougeault, P.; Ducrocq, V.; Duron, J.; Fischer, C.; Héreil, P.; Mascart, P.; Masson, V.; et al. The Meso-NH Atmospheric Simulation System. Part I: Adiabatic formulation and control simulations. Ann. Geophys. 1998, 16, 90-109. [CrossRef]

53. Lac, C.; Chaboureau, J.P.; Masson, V.; Pinty, J.P.; Tulet, P.; Escobar, J.; Leriche, M.; Barthe, C.; Aouizerats, B.; Augros, C.; et al. Overview of the Meso-NH model version 5.4 and its applications. Geosci. Model Dev. 2018, 11, 1929-1969. [CrossRef]

54. Mlawer, E.J.; Taubman, S.J.; Brown, P.D.; Iacono, M.J.; Clough, S.A. Radiative transfer for inhomogeneous atmospheres: RRTM, a validated correlated-k model for the longwave. J. Geophys. Res. 1997, 102, 16663-16682. [CrossRef]

55. Cuxart, J.; Bougeault, P.; Redelsperger, J.L. A turbulence scheme allowing for mesoscale and large-eddy simulations. Q. J. R. Meteorol. Soc. 2000, 126, 1-30. [CrossRef]

56. Verrelle, A.; Ricard, D.; Lac, C. Sensitivity of high-resolution idealized simulations of thunderstorms to horizontal resolution and turbulence parametrization. Q. J. R. Meteorol. Soc. 2015, 141, 433-448. [CrossRef]

57. Pergaud, J.; Masson, V.; Malardel, S.; Couvreux, F. A Parameterization of Dry Thermals and Shallow Cumuli for Mesoscale Numerical Weather Prediction. Bound. Layer Meteorol. 2009, 132, 83. [CrossRef]

58. Pinty, J.-P.; Jabouille, P. A mixed-phase cloud parameterization for use in mesoscale non-hydrostatic model: Simulations of a squall line and of orographic precipitation. In Proceedings of the Conference of Cloud Physics, Everett, WA, USA, 17-21 August 1998; pp. 217-220.

59. Masson, V.; Moigne, P.L.; Martin, E.; Faroux, S.; Alias, A.; Alkama, R.; Belamari, S.; Barbu, A.; Boone, A.; Bouyssel, F.; et al. The SURFEXv7.2 land and ocean surface platform for coupled or offline simulation of earth surface variables and fluxes. Geosci. Model Dev. 2013, 6, 929-960. [CrossRef]

60. Kalnay, E.; Kanamitsu, M.; Kistler, R.; Collins, W.; Deaven, D.; Gandin, L.; Iredell, M.; Saha, S.; White, G.; Wiillen, J.; et al. The NCEP/NCAR 40-Year Reanalysis Project. Bull. Am. Meteorol. Soc. 1996, 77, 437-472. [CrossRef]

61. NOAA/ESRL Physical Sciences Laboratory. Available online: https:/ / psl.noaa.gov/data/composites/hour/ (accessed on 16 December 2020).

62. Alves, J.M.R.; Caldeira, R.M.A.; Miranda, P.M.A. Dynamics and oceanic response of the Madeira tip-jets. Q. J. R. Meteorol. Soc. 2020, 146, 3048-3063. [CrossRef]

63. Belo-Pereira, M.; Santos, J.A. Air-Traffic Restrictions at the Madeira International Airport Due to Adverse Winds: Links to Synoptic-Scale Patterns and Orographic Effects. Atmosphere 2020, 11, 1257. [CrossRef]

64. Etling, D. On atmospheric vortex streets in the wake of large islands. Meteorl. Atmos. Phys. 1989, 41, 157-164. [CrossRef] 
65. Stull, R.B. Introduction to Boundary Layer Meteorology; Kluwer Academic Publisher: New York, NY, USA, 1988.

66. Sharples, J.J.; Mills, G.A.; McRae, R.H.D.; Weber, R.O. Foehn-Like Winds and Elevated Fire Danger Conditions in Southeastern Australia. J. Appl. Meteorol. Climatol. 2010, 49, 1067-1095. [CrossRef] 